Working Paper in Economics No. 697

\title{
Cost Pass-Through in the Swedish Coffee Market
}

Dick Durevall

Department of Economics, March 2017 


\title{
Cost Pass-Through in the Swedish Coffee Market
}

\author{
Dick Durevall* \\ HUI Research and the University of Gothenburg
}

$16 / 03 / 2017$

\begin{abstract}
Cost pass-through to retail prices shows how changes in marginal costs are allocated between producers and consumers, and it is therefore closely related to market structure and competition. This paper uses Swedish data on coffee products at the barcode level to evaluate pass-through from the cost of green coffee beans, the main marginal cost, to the retail price of roasted and ground coffee. First long-run cost pass-through is estimated for each product, and then regression is used to analyse how pass-through varies across market shares, retailer-owned brands and other product characteristics. A general result is that pass-through is roughly complete for products with large market shares, while those with small market shares have low pass-through rates. There is no evidence that retailer-owned brands have higher pass-through than brand-name products with similar market shares, which would be the case if retailer-owned brands avoided double marginalization through vertical integration. Thus, although there is not perfect competition in the Swedish coffee market, a large part of it appears to be highly competitive.
\end{abstract}

JEL codes: L11, L13, L89

Keywords: Coffee market, Market power, Pass-through, Market shares

*Department of Economics, School of Business, Economics and Law at University of Gothenburg, P.O. Box 640, SE 405 30, Gothenburg, Sweden, E-mail: dick.durevall@gu.se 


\section{Introduction}

Many consumer markets for coffee are characterized by a few dominant multinational or national roasters, with a combined market share often exceeding $60 \%$, and a large number of small roasters and importers (Sutton, 2007). Not surprisingly, the large roasters are regularly alleged to charge high prices for processed coffee relative to the price of their main input, i.e. green coffee beans. ${ }^{1}$ The rapid growth of Fairtrade coffee sales, which increased by about 1,400\% between 2000 and 2015, is probably a result of these allegations (Fairtrade Foundation, 2012; Fairtrade International, 2017).

Nevertheless, there is little empirical evidence of market power in consumer coffee markets for roasted and ground coffee. In fact, most studies find no or a tiny mark-up of price over marginal cost in Sweden and other developed countries (Bettendorf and Verboven, 2000; Feuerstein, 2002; Durevall, 2007a, 2007b; Gibbon, 2007; Gilbert, 2007; 2008). However, these studies treat coffee as a homogeneous product, due to paucity of data, and therefore fail to capture important market features (Sexton, 2013). A few recent studies analyse pass-through from marginal costs to retail prices using product-level data and find cost pass-through to be incomplete, i.e. less than 1 in the US (Leibtag et al., 2007; Nakamura and Zerom, 2010), and far below 1 in Germany and France (Bonnet et al., 2013; Bonnet and Villas-Boas, 2016). The low pass-through indicates that there is imperfect competition and that prices are higher than marginal costs.

This paper analyses how changes in marginal costs, measured by fluctuations in world market green coffee bean prices, are passed on to Swedish retail coffee prices and how pass-through rates are related to market structure. As in previous studies, I focus on roasted ground coffee since green beans is the major input in the production process. Moreover, ground coffee has a market share of $80 \%$ in the Swedish retail market.

The Swedish coffee retail market is likely to be representative of many other markets in developed countries (Durevall, 2003; Sutton, 2007). In the ground coffee segment, the four largest roasters have a combined market share of about $85 \%$. There are a few retailer-owned brands (private labels), several small, mostly local, roasters and some foreign brands.

\footnotetext{
${ }^{1}$ See e.g. Dicum and Luttinger (1999), Fitter and Kaplinsky (2001), Oxfam (2002), Gooding (2003), Moore (2003), McCorriston et al. (2004), Talbot (2004, 2011), Consumers International (2005), Daviron and Ponte (2005), Green (2005), Gibbon (2007), Levy (2008), Fairtrade (2012) and World Vison (2014).
} 
Moreover, as in most developed countries, the retail sector is very concentrated (McCorriston, 2013). For example, the largest food chain has about $50 \%$ of the market and the four largest account for well over $90 \%$ of all sales (Swedish Competition Authority, 2011).

The retail price data are from the Nielsen company, which collects information from food store cash registers across Sweden. I use data on 68 ground coffee products sold in six regional markets from March 2009 to November 2014, yielding 378 coffee product/regional market combinations (not all coffee products are sold in all markets). For simplicity, I refer to product/regional market combinations as products and coffee products, such as Gevalia 0.500 kg Mellanrost Brygg, as coffees. There are 20 brands (plus a category called Other Brands), of which six are private labels. Prices are measured as value divided by volume, averaged over region since store-level data are not available in Sweden. To measure costs, I use the price of green coffee beans, adjusted for weight lost due to roasting. The cost of beans is estimated to equal 50\%-90\% of marginal costs (Bettendorf and Verboven, 2000; Nakamura and Zerum, 2010; Bonnet et al., 2013).

The first part of the study uses unrestricted error correction models to estimate long-run passthrough of industry-wide shocks to marginal costs for each individual product. The choice of model is based on the high persistence of the green bean price series, which can be characterized as unit root non-stationary. The unit root implies that bean prices should be cointegrated with the retail price for costs to have long-run impact, given other input costs.

Since I also have data on quantities, in contrast to most other studies, the second part uses regression analysis to analyse the relationship between market structure and pass-through. Horizontal market structure is measured by product, coffee and brand market shares, and vertical market structure is measured by the presence of private labels. It is a common assumption that products with a large market share have a lower pass-through than products with small market shares, due to higher markup and more market power. This is what the Dornbusch (1987) model of monopolistic competition predicts, a model widely used in international economics (Burstein and Gopinath, 2014; Feenstra, 2016). Vertical integration, in the form of private labels, sidesteps the market power of manufacturers of branded products and should prevent double marginalization, i.e. when a downstream firm (retailer) applies a markup on a price set by an upstream firm (roaster) that has market power and 
therefore also applies a markup. Avoidance of double marginalization should lead to higher pass-through, given market share (Hong and Li, 2015). Therefore, by controlling for market shares, I can indirectly evaluate whether there is double marginalization.

Finally, as a robustness check, I use the cointegrated VAR model of Johansen (1991) to analyse cost pass-through and adjustment to cost shocks in one regional market, eastern Sweden. I focus on four dominant coffees, which together have a market share of close $50 \%$. The Johansen approach allows me to formally test whether there is perfect pass-through and evaluate the speed of adjustment to cost shocks.

The average pass-through for all products in the sample is estimated to be 0.77 SEK for a 1 SEK change in costs, when negative pass-through rates are set to zero. Bonnet et al. (2013) estimate the average pass-through rate to be below 0.3 in the German market, while Bonnet and Villas-Boas (2016) estimate the pass-through elasticity ${ }^{2}$ in the French market to be as low as 0.011 for cost increases and 0.007 for cost decreases. Nakamura and Zerom (2010) obtain a pass-through rate of about 0.9 for the US market. The large differences in estimates are probably due to the combined effect of sample period, the model specification and differences across markets. However, all studies find that average pass-through is incomplete.

A key finding in the present paper is that pass-through rates are highly dispersed, with some rates being zero and others slightly over 1 SEK. As these estimates include both the direct effect of the change in costs and the indirect effects due to strategic interaction, market structure may play a key role in explaining the dispersion. In fact, the four large brands, each of which sells several coffees, have average pass-through rates that are 0.30-0.40 SEK higher than other brands. The only study I am aware of that reports individual pass-through estimates for roasters is Bonnet et al. (2013), and they, too, find substantial differences. However, it is not straightforward to compare their findings with mine since their study is limited to five big roasters and reports only pass-through elasticities. Moreover, they do not analyse the relationship between market share and pass-through.

\footnotetext{
${ }^{2}$ Many studies only estimate pass-through elasticities. However, evaluation of pass-through rates, i.e., in SEK, facilitates the analysis since an increase in marginal cost by 1 SEK would increase the price by 1 SEK when passthrough is complete, by less than 1 SEK when it is incomplete and by more than 1 SEK when there is overshifting. A pass-through elasticity is complete when pass-through corresponds to a price increase equal to the (often unknown) share of marginal cost of the analysed cost component.
} 
Another key finding is that the association between pass-through and market share is positive, though non-linear as a pass-through of about 1 seems to be an upper limit. This relationship seems to primarily be due to the market share of the coffee and not the brand, i.e. passthrough rates are low for coffees with small market shares irrespective of whether they are of a large or small brand. This finding of a positive association between pass-through and market share is the opposite of the prediction of Dornbusch's (1987) model and the findings of Atkeson and Burstein (2008) and Hong and Lee (2015), among others.

Yet another finding is that vertically integrated coffees do not have high pass-through rates, which is contrary to the results of Hong and Lee (2015). Discount, and to some extent premium, private labels have low pass-through rates relative to their market shares, while standard private labels have pass-through rates consistent with their market shares. Thus, there is no evidence of double marginalization.

The cointegration analysis of the dominant coffees in eastern Sweden strengthens earlier findings. It is not possible to reject a pass-through rate of 1 for any of the four products. ${ }^{3}$ The adjustment to a cost shock takes about a year to be completed, probably due to the combined effect of the time it takes to process coffee beans, the existing stocks in food stores and the bargaining between roasters and retail chains.

Since the four largest coffees have a volume market share of about $50 \%$ and the ten largest a market share of nearly $70 \%$, the finding of pass-through rates of about 1 for large coffees indicates that a substantial part of the Swedish coffee market is highly competitive. One reason earlier studies on the Swedish coffee market have not found evidence of market power is most likely their use of average retail prices collected by Statistics Sweden, which were based on a small selection of prices of popular coffees. ${ }^{4}$ The question is why products with small market shares have low pass-through rates and vice versa. One hypothesis is that it is due to the functional form of consumer demand function, which would have to be concave and vary systematically across market shares, such that the smaller the market share the larger the response of the price elasticity to a price change. However, it is not obvious why

\footnotetext{
${ }^{3}$ The behaviour of large coffee retail prices is similar in the other five regional markets (not reported).

${ }^{4}$ Since 2012, Statistics Sweden uses cash register data to construct indexes of food retail prices. Prior to that year, small samples of products were selected randomly with a probability based on their market share (Statistics Sweden, 2007, 2014). As a result, the series of average prices reported by Statistics Sweden for ground coffee primarily comprised coffees with large market shares.
} 
the demand for small coffees should respond more to price changes than the demand for large coffees. Another hypothesis is that the regularly occurring bargaining between roasters and retail chains generates the relationship. Roasters might face strong resistance from retail chains when they wish to raise the wholesale prices of coffees with small market shares, since retailers prefer to fill their shelves with the most popular coffees or their own brands. And retail chains might be reluctant to lower the retail prices of small coffees when wholesale prices go down, since they wish to increase their markups on coffees that sell little. Prices on large coffees, on the other hand, are changed when costs change, because both roasters and retailers compete on market shares.

The paper is organized as follows: Section 2 gives a brief review of why pass-through rates might vary across firms and of the findings of earlier studies. Section 3 describes the data and Section 4 outlines the empirical approach. Section 5 estimates pass-through rates and analyses the role of market structure, while Section 6 uses the cointegrated VAR model to analyse prices and costs of large coffees in eastern Sweden. Section 7 concludes the paper.

\section{Pass-through, Demand, and Market Structure}

Pass-through of costs to prices has been a research topic for a long time, particularly in the fields of marketing and agricultural and public economics (Bulow and Pfleiderer, 1983; Tyagi, 1999; Weyl and Farbinger, 2013). Several studies on the topic have recently been published in the field of international economics as well, and have mainly focused on the effect of changes in exchange rates on consumer prices (Burstein and Gopinath, 2014).

Several factors may affect pass-through, and no model captures all of them. Thus, for expository purposes, I use a Bertrand model from Anderson et al. (2001) to illustrate the key ones when there are industry-wide changes in costs, conveniently measured by a unit tax. ${ }^{5}$ । then informally discuss other factors of relevance to the retail coffee market. ${ }^{6}$

The model has $N$ firms that each produces one differentiated product, $q$, at constant marginal cost $c$. The profit function of firm $i$ is

\footnotetext{
${ }^{5}$ Since my measure of marginal cost is an industry-wide cost shock, the study is related to studies on tax incidence and on studies in international economics that analyse the effect of exchange rate changes on retail prices.

${ }^{6}$ See RBB (2014) for a general review of pass-through.
} 


$$
\pi_{i}=\left[p_{i}-\left(c_{i}+t\right)\right] q\left(p_{i}, p_{-i}\right)
$$

where $p_{i}$ is firm i's price, $p_{-i}$ is the set of all other firms' prices, $q\left(p_{i}, p_{-i}\right)$ is the demand for the output of firm $i$, and $t$ is the unit tax. Profit maximization gives the first-order condition

$$
\left[p_{i}-\left(c^{\prime}{ }_{i}+t\right)\right] \frac{\delta q_{i}\left(p_{i}, p_{-i}\right)}{\delta p_{i}}+q_{i}\left(p_{i}, p_{-i}\right)=0
$$

Pass-through is obtained by total differentiation with respect to $t$. By assuming symmetry between the firms, we can derive an expression for pass-through based on elasticities (see RBB, 2014 for details):

$$
\frac{d p_{i}}{d t}=\frac{1}{1+\frac{\varepsilon_{D D}}{\varepsilon_{d d}}-\frac{\varepsilon_{m}}{\varepsilon_{d d}}}
$$

where the numerator of the first ratio, $\varepsilon_{D D}$, is firm i's price elasticity with respect to a shift in all prices. It is defined as

$$
\varepsilon_{D D}=\frac{p}{q} \frac{\partial q_{i}}{\partial p}=\frac{p}{q}\left[\frac{\partial q_{i}}{\partial p_{i}}+\frac{\partial q_{i}}{\partial p_{-i}}\right]
$$

The denominator of the ratio is firm i's price elasticity with respect to a shift in its own price, given all other prices:

$$
\varepsilon_{d d}=\frac{p}{q} \frac{\partial q_{i}}{\partial p_{i}}
$$

The second ratio is the elasticity of the slope of firm i's demand curve with respect to the common price

$$
\varepsilon_{m}=\frac{p}{\partial q_{i} / \partial p_{i}} \frac{\partial\left(\partial q_{i} / \partial p_{i}\right)}{\partial p}
$$

divided by firm i's price elasticity with respect to its own price, $\varepsilon_{d d}$.

The first ratio in the denominator of Equation (3) can be written as 1 minus the diversion ratio, $D$, using the assumption of symmetry, 


$$
\frac{\varepsilon_{D D}}{\varepsilon_{d d}}=\frac{\frac{p}{q}\left[\frac{\partial q_{i}}{\partial p_{i}}+\frac{\partial q_{i}}{\partial p_{-i}}\right]}{\frac{p}{q} \frac{\partial q_{i}}{\partial p_{i}}}=\frac{\left[\frac{\partial q_{i}}{\partial p_{i}}+\frac{\partial q_{-i}}{\partial p_{i}}\right]}{\frac{\partial q_{i}}{\partial p_{i}}}=1-D .
$$

The diversion ratio is the share of firm i's sales that is captured by other firms when firm $i$ raises its price. Inserting 1-D in Equation (3), we get

$$
\frac{d p_{i}}{d t}=\frac{1}{2-D-\frac{\varepsilon_{m}}{\varepsilon_{d d}}} .
$$

Equation (8) shows that pass-through is determined by the diversion ratio, the curvature of the demand function, and the firm's price elasticity. In the case of complete product differentiation, that is, firm $i$ is a monopolist, then $D=0$ and the value of the ratio between slope elasticity of the demand curve, $\varepsilon_{m}$, and the price elasticity, $\varepsilon_{d d}$, determines passthrough. For instance, when demand is linear, $\varepsilon_{m}=0$, we have the textbook case of a passthrough of $1 / 2$.

It is reasonable to assume that $D$ is generally higher the more firms there are in the market, since then there is more competition. Thus, as competition (the number of firms) increases, $D$ approaches 1 and pass-through approaches 1 . Consequently, even when demand is linear, pass-through can be 1. However, competition will also increase firm i's price elasticity, and when there is perfect competition, the ratio $\varepsilon_{m} / \varepsilon_{d d}$ will be zero irrespective of the slope elasticity of the demand curve.

With monopolistic competition and a given $D$, the curvature of the demand function determines pass-through. When demand is concave, the slope of the demand curve becomes flatter as the price increases, i.e. the firm loses sales rapidly when raising prices. As a result, pass-through is low since $\varepsilon_{m}$ increases with price. When demand is convex, $\varepsilon_{m}$ declines when the price increases, and it is possible that pass-through is over 1.

There are several multiproduct roasters in the Swedish coffee market, which is not captured by the model. A few studies analyse pass-through in theoretical models where firms produce more than one good, and the results depend on assumptions about functional form and the size of second-order effects (Besanko et al., 2005; Moorthy, 2005). However, by developing 
a structural model for the Swedish beer market, Romahn and Friberg (2016) provide evidence that multiproduct firms are likely to have lower pass-through than single-product firms, both when there are industry-wide and firm-specific cost shocks. A multiproduct firm will consider all its products jointly when it sets optimal prices, taking into consideration that an increase in one of its prices will divert some sales to the firm's other products. The diversion reduces the required adjustment after a cost shock, compared with a singleproduct firm. However, the difference in pass-through between a single and a multiproduct firm may be small unless the multiproduct firm sells very many products, making it challenging to detect differences in an observational study.

The shape of the cost function may also affect pass-through. An upward-sloping marginal cost function decreases pass-through both in perfectly competitive and oligopolistic markets. The size of the effect depends on the ratio between the elasticities of supply and demand; the smaller the supply elasticity the smaller the pass-through, given demand elasticity. Nonetheless, the assumption of constant marginal costs is standard in the literature on coffee since processing of ground coffee is highly mechanized, but simple, and involves only a few workers (Bettendorf and Verboven, 2000; Sutton, 2007; Nakamura and Zerom, 2010). Moreover, as coffee consumption in Sweden is small relative to the world supply of beans, demand does not affect bean prices. Therefore, upward sloping marginal costs are unlikely to have a major impact on pass-through.

Some models allow for heterogeneous firms (Dornbusch, 1987; Feenstra, 2016, Ch. 6). In these models there is usually a negative relationship between market share and passthrough: firms with large market shares have large markups and adjust the markup instead of the price after a change in marginal costs. Several studies also find a link between the degree of product pass-through and horizontal market structure (Atkeson and Burstein, 2008; Amiti et al., 2014; Hong and Li, 2015; Auer and Schoenle, 2016). ${ }^{7}$

\footnotetext{
${ }^{7}$ The Dixit-Stiglitz model of monopolistic competition has identical firms and constant markup, and thus a passthrough rate of 1 . Dornbusch (1987) introduces the assumption that firms take the effect of its own price on the overall price index into account, which makes pass-through lower the larger the impact a firm's price has on the price index. The Dornbusch (1987) model has become a workhorse in international economics (Burstein and Gopinath, 2014).
} 
Most ground coffees are brand-name products processed and distributed to retailers by roasters. When upstream and downstream firms, i.e. roasters and retailers, have market power, there might be double marginalization. ${ }^{8}$ As a result, there is markup on markup, and pass-through is lower than when a monopolist owns both the upstream and downstream firms. The number of private labels has been increasing for several years in many countries, including Sweden. This can be seen as vertical integration, since products without the manufacturers' label are introduced. Private labels are expected to have a higher passthrough than brand-name products since they sidestep the roasters' markup, though a large market share would have a counterbalancing effect. However, by controlling for market shares, Hong and Li (2015) show that private labels in the US have substantially higher passes-through rates than branded products.

In Sweden, large roasters and retail chains meet regularly to negotiate wholesale prices, so relative bargaining power and pricing contracts could influence pass-through. ${ }^{9}$ Thus, double marginalization could be prevented by outright collusion, though this is illegal and unlikely given the number of actors. However, there are many types of vertical contracts. Based on simulation of structural models, Bonnet et al. (2013) find evidence of resale price maintenance in the German ground coffee market, which increases pass-through relative to double marginalization.

Finally, the model is static and pass-through is treated as the equilibrium price response to a change in costs, ignoring dynamics. Nakamura and Zerom (2010) examine short-run adjustments in the US coffee market using a structural model. They find that menu costs matter in the short run but not after a year or so. A related question is whether prices rise faster than they fall after a change in marginal costs (Peltzman, 2000). Nakamura and Zerom (2010) do not find robust evidence that coffee prices systematically react asymmetrically, but three coffee market studies find that cost increases are passed on faster to retail prices than cost decreases: Gómez et al. (2009) and Lee and Gómez (2013) apply time series methods to average market data from the US, France and Germany, and Bonnet and Villas-Boas (2016) estimate and simulate a structural model based on product data from France. Asymmetry is

\footnotetext{
${ }^{8}$ Adachi and Ebina $(2014 a, 2014 b)$ discuss the case of vertical relationships with homogeneous manufacturers and retailers in detail.

${ }^{9}$ See Gaudin (2016) for the role of relative bargaining power between wholesalers and retailers in determining pass-through.
} 
primarily a short-run phenomenon, which I ignore in the present study since it is difficult to identify with six years of data when costs are highly persistent (see Figure 1).

Thus, to conclude, studies of market power in coffee retail markets, which assume that coffee is a homogenous product and use average market prices, fail to find evidence of market power (Gibbon, 2007), while those that use product-level data find pass-through rates that are below 1 and conclude that there is imperfect competition. Assuming highly elastic supply, a passthrough rate below or above 1 is evidence against perfect competition. However, as evident from theory, the presence of a pass-through rate of 1 is neither a necessary nor a sufficient condition for perfect competition. Yet, by analysing how pass-through of individual products is related to horizontal and vertical integration, an informed judgement can be made. Previous studies on product-level data focus on average pass-through, though based on individual product prices.

\section{The Data}

The retail data are from the Nielsen company, which collects weekly scanner data on value and volume at the EAN (barcode) level of daily sales from 3088 Swedish stores. Coffee is grouped into seven market segments, but I focus on the by far largest segment, roasted and ground coffee. Nielsen also collects information on a number of product characteristics, such as brand, manufacturer and whether the product is organic. I use this information to distinguish between pass-through rates for the major brands, three types of private labels (discount, premium, and standard) and conventional and organic coffee; as all Fairtrade coffee is organic, it is not modelled separately.

Unfortunately, Nielsen does not make store-level information available in Sweden, so values and volumes are averages for six regional markets. I use monthly averages to reduce the number of missing observations (all products are not sold every week) and the noise-toinformation ratio; it clearly takes more than a week for a change in coffee bean prices to affect retail prices. Prices, obtained by dividing value by volume, are in Swedish kronor (SEK) per kilo at the barcode level by region.

One feature of retail prices is that they sometimes decrease due to sales, but there is no information in the database on sales. Some studies filter the price series to remove temporary 
decreases and analyse normal prices or reference prices (Eichenbaum et al., 2011; Lloyd et al., 2014). However, my prices are averages by region, not individual store prices, so it is not clear what would be filtered out. Moreover, I analyse a relatively long period, almost six years, and sales are not synchronised across food chains, so occasional sales probably only have a minor impact on pass-through rates. I therefore use actual prices (i.e. unit values) in the analysis.

Since I analyse individual time series, products with missing observations have been dropped. They amount to $12 \%$ of the sample in volume terms. Most of them are coffees that were introduced in, or removed from, the market during the study period. As Table 1 shows, the sample thus consists of 378 products and 68 coffees, belonging to 20 brands (plus unspecified Other Brands), and runs from March 2009 to November 2014. Almost all roasters produce one brand. The noteworthy exception to this is Gevalia, which produces three brands: Gevalia, Blå Mocca and Maxwell House.

The market is highly concentrated; the two largest brands, Gevalia and Zoegas have $39 \%$ and $27 \%$ of the ground coffee market (in volume terms) and are owned by Mondelez and Nestlé, respectively. The market shares of the other two large brands, Classic and Löfbergs Lila, are $14 \%$ and $6 \%$, respectively. They are produced by family-owned roasters. The brands ICA, Coop, Änglamark, ICA I Love Eco and Euroshopper are private labels, the other brands are produced by small Swedish roasters or imported.

There is no information on commodity costs for manufacturers or brands, so green coffee bean prices in SEK are used to measure cost shocks. There are two sources for bean prices: the International Coffee Organization (ICO) collects price data from terminal markets in Europe and the US, and Statistics Sweden publishes value and volume of monthly imports of green coffee beans. I use prices based on import data from Statistics Sweden, but the choice does not matter much for the results, except that ICO prices take longer to affect retail prices. The reason for the similarity between of import prices and prices set at the commodity exchanges is that the latter function as price guides for physical coffee trade (International Trade Centre, 2011)

Table 1 also shows that average real retail prices (net of VAT) vary from 34 SEK to 109 SEK per $\mathrm{kg}$, which can be compared with the average cost of green coffee beans of 32.60 SEK. To highlight the evolution of prices over time, Figure 1 shows the average price of unweighted 
ground coffee and cost of green coffee beans, measured by the bean price times 1.19 to account for weight lost from roasting. ${ }^{10}$ Both series are measured in constant 2010 prices using the consumer price index. There were large changes in prices and costs during the study period. The average per kg price of ground coffee fluctuated between 60 SEK and 80 SEK, and the cost of green coffee beans fluctuated between 20 SEK and 45 SEK per kg. Figure 1 also shows that the series are highly persistent; when the augmented Dickey-Fuller (ADF) test is applied on the individual retail prices, only about 10 to 15 tests reject the null hypothesis of a unit root (results available on request). The bean price series also appears to have a unit root: the ADF test with one lag (longer lags are insignificant), a constant, and a time trend gives a tvalue of -1.4 ( $5 \%$ significance value is -3.47$)$ and an estimated root of 0.97 .

\section{Empirical Approach}

The most commonly used model to estimate pass-through is the distributed lags model in rates of change, i.e. the first difference of the log-level of prices and costs (Nakamura and Zerom, 2010; Aron et al., 2014), ${ }^{11}$ though Bonnet and Villas-Boas (2016) and Bonnet et al. (2013) estimate static fixed effects models in log levels. One reason for using rates of change is probably that often only price indexes are analysed in international economics and the focus is on changes in the exchange rate. Another reason is the risk of spurious correlation, since some series might be unit-root non-stationary.

A drawback of using first differences is that important information about the long-run passthrough is ignored if the series have unit roots and are cointegrated, which, as evident from Figure 1, seems to be the case for ground coffee. Thus, I estimate models in levels. Spurious regression is unlikely to be a major issue for ground coffee, since the cost of green coffee beans is the by far largest component of marginal cost (Bettendorf and Verboven, 2000; Nakamura and Zerum, 2010; Bonnet et al., 2013). Moreover, bean costs usually fluctuate much more than other production-related costs, and this was true for Sweden during the

\footnotetext{
${ }^{10}$ The weight lost from roasting is common knowledge. See e.g. European Coffee Federation (2011).

${ }^{11}$ Hassouneh et al. (2012) provide a review of approaches used when analysing fairly long time series of market data.
} 
study period, when compared with wages and the consumer price index. ${ }^{12}$ Bean costs and retail coffee prices are therefore expected to have the same stochastic trends. However, some retail prices are stationary, as mentioned, and some could be non-stationary but unrelated to costs, implying that long-run pass-through is zero. This could occur because real retail prices are kept more or less fixed over the study period, or because of large abrupt price changes due to revised price policies. In these cases, the pass-through estimates are small or in some cases even negative.

Static models in levels are easy to estimate and might provide adequate long-run pass-through rates when the variables are integrated of order one and cointegrated. However, a static model with monthly data is not likely to capture the dynamics adequately; i.e. the common factor restriction (implicitly) imposed is often invalid (Ericsson and MacKinnon, 2002). It might also fail to provide consistent estimates of pass-through when the dependent variable is stationary and lags are needed to specify the model correctly. I therefore estimate passthrough coefficients for each product using an unrestricted error correction model specified as

$$
\Delta p_{t}=\alpha+\alpha_{1} \Delta p_{t-1}+\alpha_{2} \Delta \operatorname{cost}_{t-1}+\beta_{1} p_{t-1}+\beta_{2} \operatorname{cost}_{t-1}+\text { trend }+\varepsilon_{t},
$$

where $p_{t}$ is the price level of a product at month $t$, cost is the price of one $\mathrm{kg}$ of green coffee beans adjusted for weight lost from roasting, $\Delta$ is the difference operator, $\beta_{1}$ and $\beta_{2}$ are the parameters of interest, $\beta_{2} /-\beta_{1}$ is the estimate of long-run pass-through and $\varepsilon_{t}$ is the error term. The lags in first differences, $\Delta p_{t-1}$ and $\Delta \operatorname{cost}_{t-1}$, potentially improve the estimates of $\beta_{1}$ and $\beta_{2}$ by capturing short-run dynamics. Adding more lags only affects the estimates of $\beta_{2} /-\beta_{1}$ marginally and does not change any of the results. trend is a deterministic trend that potentially captures other marginal costs and slow-moving changes in technologies.

I do not base the subsequent analysis on tests for cointegration of each of the 378 equations, but very low or negative pass-through rates indicate a lack of a long-run relationship. However, I also estimate distributed lags models in first differences and static models in levels.

\footnotetext{
12 If we assume that other marginal costs followed the consumer price index, as Bettendorf and Verboven (2000) do, they would have increased, roughly monotonically, by about $5 \%$ in total over the study period. Wage costs probably increased a bit more, but they make up a small components of costs (Durevall, 2007b).
} 
Moreover, as robustness check, in Section 6 I formally test for coingration in a multivariate framework in one of the six regional markets using the battery developed by Johansen (1991).

\section{Pass-Through Rates and the Role of Market Structure}

Figure 2 reports the estimates of the pass-through rates. ${ }^{13}$ The vast majority are larger than zero, as expected. Those with negative pass-through are mostly odd products with almost constant prices and very small market shares. One product with a pass-through rate of 2.1 is excluded from the figure to improve readability; a detailed analysis revealed that the high value is due to a large structural break at the end of the sample.

Most pass-through rates fall in the 0.5-1 range. This is also the case when long-run passthrough is estimated with a static model in levels, though the pass-through rates are somewhat lower on average (see Figure A1 in the appendix). The correlation between the two measures is 0.92 . When pass-through rates are estimated with distributed lags models in first differences, the pass-through rates are clearly lower, as Figure A2 in the appendix shows. The models have 24 lags, but adding more lags does not increase pass-through rates. Thus, distributed lags models seem to underestimate the size of the pass-through rates since they do not use information contained in the levels of the variables.

Some estimates are larger than 1, but this is probably due to estimation uncertainty; almost no $95 \%$ confidence interval excludes the value of 1 . Thus, there is no evidence of highly convex demand functions, i.e. functional forms that generate pass-through larger than 1.

Figure 3 depicts the estimated pass-through coefficients and market shares, in logs for visibility, for the 68 coffees. It shows that the larger the market share, the higher the passthrough. This relationship is contrary to the prediction of models in which the size of the market share is related to market power, indicating that coffees with large market shares compete for customers. The relationship is also non-linear, as a pass-through rate of 1 seems to constitute a (fuzzy) upper limit.

Table 2 reports regressions that test for the association between pass-through rates and market shares. Since it is not obvious how to measure market shares, three measures are

\footnotetext{
${ }^{13}$ Since I estimate about 1000 regressions, the key results are reported in graphs. The actual estimates are available on request.
} 
used: product, coffee and brand market shares. To capture the non-linear relationship, both level and squared market share terms are included.

Nor is it obvious how to deal with very low and negative pass-through rates, which presumably are zero. Hong and Li (2015) simply exclude products with negative pass-through in their analysis. However, two types of products have negative pass-through rates, private labels and imported coffee from brands primarily sold to immigrant groups. Thus, instead of removing all of them, I include a dummy for Najjar and Bosnia (Zlatna Dzezva) products, which make up about half of those with negative pass-through rates. The others are primarily private labels, which are of interest for the study. I also estimated models with all pass-through rates below 0.1 set to zero, but the results only changed marginally (the results are available on request).

Table 2 shows that there is a strong positive, but non-linear, association between passthrough and market share. For example, at the median coffee market share, 0.005 , the passthrough is 0.70 , and at a coffee market share of 0.05 , it is 0.84 . Market shares measured at the coffee level have a somewhat larger explanatory power than the others, while the lack of significance for brand shares might be because of the relatively small number of brands, but most likely it is because the product and coffee levels matter more for pricing decisions than the brand level (as shown below).

Table 3 reports specifications that aim to further describe differences in pass-through. Column (1) adds three types of private labels (discount premium, and standard), type of roast (dark and unspecified; the base is medium roast) and organic coffee to Table 2's column (2). Private labels should have a higher pass-through in monopolistic markets, given market share, since they avoid potential double marginalization. However, both discount and premium private labels have a lower pass-through rate than other coffees, while the standard one has the same rate, given market shares. The dummies for dark roast and organic coffee are insignificant, while unknown roast is significant at the $5 \%$ level. The coefficients of product market share and squared product market share are unaffected by the inclusion of the other variables.

Column (2) replaces market shares with dummies for the four large brands. They are all significant at the $1 \%$ level and show that the large brands have pass-through rates that on average are about 0.3-0.4 SEK higher than the other brands. Column (3) shows that these results are not due to the other variables included in the model. 
Column (4) restricts the sample to the four large brands to test whether pass-through rates differ across their products. Although the market share coefficients have the same signs as in the other regressions, they are much smaller and insignificant. However, two of the large brands, Gevalia and Classic, have pass-through rates that vary with market shares, as reported in columns (5) and (6). This is not the case for the other two, Löfbergs Lila and Zoega (not reported).

Figure 4 sheds further light on the relationship between pass-through and the 20 brand market shares. Average pass-through rates are similar for the four largest brands, but there is a fairly large variance among the products of each brand. Moreover, it is clear that only very small brands have pass-through rates close to, or below, zero.

\section{Analysis of Large Coffees in the Eastern Swedish Market}

To provide additional support to the findings that a substantial part of the Swedish coffee market is competitive, I use the cointegrated VAR model and the Johansen approach to analyse pass-through and dynamic price interaction among large coffees. I focus on one market, eastern Sweden, which covers the most densely populated areas of the country, including the Stockholm region, Uppsala, Nyköping and Norrtälje. The advantage of the Johansen approach is that it allows me to formally test hypotheses about long- and short-run parameters in a multivariate setup, i.e. the size of pass-through rates and the direction of adjustment to changes in costs (Juselius, 2006; Hoover et al., 2008).

Figures 5 and 6 depict real retail prices net of VAT for the four largest coffees in terms of volume market shares nationally: Gevalia Mellanrost Brygg, Gevalia Mellanrost E-brygg, Classic Mellan Brygg and Zoegas Skånerost. The by far largest coffee is Gevalia Mellanrost Brygg, which has a market share of about $20 \%$ in eastern Sweden. Classic Mellan Brygg has a market share of $14 \%$, while Gevalia Mellanrost E-brygg and Zoegas Skånerost have about 5\% each.

As evident from the figures, all prices seem to be non-stationary and follow a pattern similar to the cost of coffee beans. Moreover, the prices of Gevalia Mellanrost Brygg and Gevalia Mellanrost E-brygg are practically identical, while Classic Mellan Brygg is a bit more expensive than the Gevalia coffees and Zoegas Skånerost is clearly more expensive. There is a notable increase in the difference between Zoegas Skånerost and the others in 2012, as the price of Zoegas declines more slowly than the other prices, but in 2014 the difference has returned to the pre-2012 level. The data is not informative of whether this deviation was a one-time event. Since the two Gevalia prices provide the same information, I drop Gevalia Mellanrost E-brygg from the analysis. 
The Johansen approach is based on the VAR model specified in error correction form:

$$
\Delta x_{t}=\alpha \beta^{\prime} x_{t}+\Gamma_{1} \Delta x_{t-1}+\Phi D_{t}+\varepsilon_{t}
$$

where $x_{t}$ is a vector of potentially endogenous variables, $\Delta$ is the first difference operator, $D$ is a vector of deterministic terms, such as constant and seasonal dummies and $\varepsilon_{t}$ is white noise (see Juselius, 2006). The lag length of the corresponding VAR in levels is set to two for illustrative purposes. The coefficients and hypotheses tested are easiest to understand if the model is (partly) written in matrix form. I assume (and later show) that there are three long-run relations (cointegrating vectors). We then have

$$
\left(\begin{array}{c}
p_{\text {Gev }} \\
p_{\text {cla }} \\
p_{\text {zoe }} \\
c_{\text {bea }}
\end{array}\right)=\left(\begin{array}{lll}
\alpha_{11} & \alpha_{12} & \alpha_{13} \\
\alpha_{21} & \alpha_{22} & \alpha_{23} \\
\alpha_{31} & \alpha_{32} & \alpha_{33} \\
\alpha_{41} & \alpha_{42} & \alpha_{43}
\end{array}\right)\left(\begin{array}{l}
\beta_{1}^{\prime} x_{t-1} \\
\beta_{2}^{\prime} x_{t-1} \\
\beta_{3}^{\prime} x_{t-1}
\end{array}\right)_{t}+\Gamma_{1} \Delta x_{t-1}+\Phi D_{t}+\left(\begin{array}{c}
\varepsilon_{1 t} \\
\varepsilon_{2 t} \\
\varepsilon_{3 t} \\
\varepsilon_{4 t}
\end{array}\right),
$$

where $p_{G e v}, p_{C l a}, p_{\text {Zoe }}$ and $c_{\text {bean }}$ are coffee retail prices and bean cost, $\alpha_{i i}$ is an adjustment coefficient, $\beta_{i}^{\prime} x_{t}$ is an error correction term for a long-run relationship and $\Gamma_{1}$ is a matrix of short-run coefficients. With four variables (each of which has a unit root) and three long-run relationships, there is one common trend, presumably resulting from the stochastic trend of the cost of coffee beans. This implies that there is a long-run relationship, $\beta_{i} x_{t}$, between each retail price and the cost of beans, though other combinations are possible, in principle. When there is complete pass-though, the coefficients of the three vectors $\beta_{1}^{\prime}, \beta_{2}^{\prime}$ and $\beta_{3}^{\prime}$ are $(1,0,0,-1),(0,1,0,-1)$ and $(0,0,1,-1)$, which is a testable hypothesis. I can also test whether $c_{\text {bean }}$ is weakly exogenous, i.e. whether $\alpha_{41}=\alpha_{42}=\alpha_{43}=0$, which would indicate that the cost of beans does not adjust to maintain any long-run relationship, a reasonable assumption given the small size of the Swedish coffee market. I can further test whether all adjustments are due to coffee bean costs or there is interaction between retail prices such that for example the price of Gevalia Mellanrost Brygg influences the adjustment of the other two prices. In this case, $\alpha_{21} \neq 0, \alpha_{31} \neq 0$. Finally, the model provides estimates of the speed of the adjustment to the long-run relationship through the values of $\alpha_{11}, \alpha_{22}$ and $\alpha_{33}$, and of whether there is short-run adjustment, $\Gamma_{1}$, due to lagged changes in $\Delta x_{t}$.

A key step in the analysis is to determine the cointegration rank (assumed to be three above), i.e. the number of long-run relationships. The Johansen approach uses the trace test, which is based on the maximum likelihood procedure. Given that I only have 66 observations, additional information should 
also be used to determine the rank (Juselius, 2001). I use the point estimates of the eigenvalues, which should be clearly larger than zero, the size of the adjustment coefficients, and economic reasoning.

Table 4 reports ADF unit root tests, trace tests, estimated coefficients and likelihood ratio test of restrictions on the system. The ADF tests (Panel 1 ) indicate that all four variables have a unit root; none of the tests statistics are significant and all estimated roots are above 0.9. Panel 2 reports the trace test statistics for the VAR model with one and two lags; the Hannan-Quinn and Schwartz information criteria clearly favoured a model with one lag, while the Akaike criterion selected a model with two lags. Adding up to five lags to the model does not change any findings. The trace test shows that there are three cointegrating vectors in the one-lag model, i.e., the rank=2 is rejected, while there are four cointegrating vectors in the two-lag model, as the rank=3 is rejected. If there were four cointegrating vectors, all variables would be stationary, contradicting the ADF unit root tests. Since the eigenvalues for rank $=4$ are close to zero $(0.04$ and 0.08$)$ and the adjustment coefficients for the coffee retail prices $\alpha_{11}, \alpha_{22}$ and $\alpha_{33}$ are large in absolute terms and the one for the cost of beans, $\alpha_{44}$, is close to zero, 0.04 (Panel 3), I proceed under the assumptions that the rank is 3 and there are three cointegrating vectors. ${ }^{14}$

Panel 4 reports the long-run coefficients for coffee prices set to either 1 or 0 in each equation. Note that no restrictions have been imposed on the system even though five long-run coefficients are zero. The estimates of the coefficients of the bean costs are all negative and close to 1 . The adjustment coefficients, also reported in Panel 4, show that all adjustments are probably due to changes in the individual coffee retail prices; there is no evidence of one coffee retail price affecting the others since all $\alpha_{i j}$ are close to zero and insignificant.

Next, I test the restrictions that all the bean cost coefficients are -1 , i.e. that the pass-through is 1 (Panel 5). The likelihood ratio test static has a p-value of 0.33 , so the hypothesis is not rejected. Then I set adjustment coefficients to zero to test whether the retail prices affect each other (Panel 6). The $\mathrm{p}$-value is $\mathbf{0 . 4 2}$, so there is no evidence that adjustment to the long-run equilibrium in one vector affects other prices.

\footnotetext{
${ }^{14}$ In principle, there may be more than one common trend in the model because of other real marginal costs. If these contained a stochastic trend, coffee retail prices would not form a cointegrating vector with coffee bean costs only. However, as mentioned, other real marginal costs evolved slowly during the study period (relative to bean prices) and they do not seem to matter for the long-run relationships. In fact, other marginal costs are captured by the intercept, as deterministic trends added to the VAR model were insignificant (not reported).
} 
Finally, to highlight the short-run dynamics, I report the vector error correction model in Table 5, where clearly insignificant lags have been excluded. ${ }^{15}$ The error correction terms are lagged two months, since it takes several weeks for the imported beans to be processed and reach the market. Yet instead lagging them one month does not alter the models much. There is fairly rapid adjustment after a change in costs for the Gevalia and Classic coffees: About $60 \%$ of a deviation from the long-run equilibrium is eliminated within a month. Moreover, lagged changes in bean costs affect the prices of Gevalia and Classic coffees, and changes in the price of Gevalia speed up changes in the price of Classic coffee in the following month.

The equations in Table 5 look unintuitive because of the negative coefficients. Thus, to see how prices evolve over time, it is convenient to re-write the error correction model into levels. Equation 12 shows models for the prices of Gevalia and Zoegas Skåne; Classic Mellanrost is similar to Gevalia,

$$
\begin{aligned}
& p_{\text {Gevt }}=c+0.24 p_{\text {Gev }, t-1}+0.18 p_{\text {Gev }, t-2}+0.50 c_{\text {bea }, t-1}+0.08 c_{\text {bea }, t-2} \\
& p_{\text {Zoet }}=c+0.50 p_{\text {zoe }, t-1}+0.24 p_{\text {Zoe }, t-2}+0.26 c_{\text {bea }, t-2} .
\end{aligned}
$$

Both prices respond to an increase in bean costs with a lag. Then there is adjustment over the following months: after a 1 SEK increase in bean cost, the price of Gevalia increases by 0.50 SEK in the following month, and reaches 1 SEK after about twelve months. The price of Zoegas adjusts somewhat more slowly after a cost increase, rising to 1 SEK over 18 months. This might be because of the sluggish price decline during period 2012-2014.

\section{Conclusion}

The purpose of this paper is to shed light on the functioning of the Swedish retail coffee market by estimating long-run pass-through rates from the cost of green coffee beans to retail prices and analysing how they are related to horizontal and vertical market structure. The focus is on roasted and ground coffee, the market segment analysed in almost all previous studies on coffee markets. The Swedish market, which is similar to other Northern European markets, has four large brands and a very concentrated food retail sector with three dominating food chains (Swedish Competition Authority, 2011). Yet, despite the high concentration, most studies fail to find evidence of market power in Sweden and other coffee consumer markets

\footnotetext{
${ }^{15}$ No contemporaneous retail prices enter the model. This is partly because I do not have any instruments, but it is primarily because there is very little correlation between the prices when measured in rates of change. I condition on current coffee bean costs in the general model since they are weakly exogenous. However, all the coefficients are insignificant, as one would expect (see Table A1 in the appendix).
} 
with similar market structure (Bettendorf and Verboven, 2000; Feuerstein, 2002; Gibbon, 2007; Durevall, 2007a, 2007b; Gilbert, 2007, 2008). These studies use average market prices and treat coffee as a homogenous product. A few recent studies use product-level data to analyse cost pass-through from green coffee beans to retail prices, which relaxes the homogeneity restriction. They find pass-through to be far below 1 in France and Germany (Bonnet et al., 2013; Bonnet and Villas-Boas, 2016), and somewhat below 1 in the US (Leibtag et al., 2007; Nakamura and Zerom, 2010). Thus, there is conflicting evidence on how competitive retail coffee markets are.

I estimate that a 1 SEK cost increase raises prices by 0.77 SEK on average when negative passthrough rates are excluded from the analysis and by 0.69 SEK when they are included. However, pass-through rates vary from about zero to slightly above 1 . Some products have pass-through rates above 1 , but only a few are significantly larger than 1 at the $5 \%$ level.

The difference in pass-through rates are largely explained by difference in market shares. The association is positive but non-linear, as a pass-through of about 1 is the upper limit. On average, the four large brands have a pass-through rate that is $0.30-0.40$ SEK higher than the other brands, while coffees with small market shares have low pass-through rates. This does not hold only for small brands, but to some extent also for large brand coffees. Several of the odd brands (aimed at immigrant groups) and discount private labels have very low, or zero, pass-through rates.

There are three types of private labels, i.e. discount, standard and premium, and none of them have higher pass-through rates than brand-name coffees, given market shares. Thus, there is no evidence of double marginalization in the Swedish ground coffee market, since this would lead to low pass-through which should be eliminated by vertical integration.

Since the market share of the four and ten largest coffees are $50 \%$ and $70 \%$, respectively, the Swedish market for roasted and ground coffee seems to be highly competitive. This result is in line with earlier studies that report no or very small markups over cost using average market prices. One reason for these earlier results is probably that the average prices used are dominated by coffees with large market shares, since Statistics Sweden prior to 2012 selected products to be measured for CPI based on sales. 
The finding of a positive association between pass-through and market share is contrary to the prediction of Dornbusch's (1987) model and the findings of earlier studies on retail prices in general (Atkeson and Burstein, 2008; Hong and Li, 2015; Auer and Schoenle, 2016). The explanation for the pass-through rates of large coffees is straightforward, i.e. a high degree of competition; the alternative, i.e. that it is due to the shape of their demand curves, seems unlikely. It is less obvious why the small coffees have low pass-through rates. One plausible explanation is that they face little competition from other coffees and have linear or concave demand functions, i.e. they are close to being monopolies. This probably applies to imported brands aimed for immigrant populations but not local brands. Another possible explanation is that given competition, they face highly concave curves, implying that a small price change leads to a large loss in sales. This concavity could be because consumers of small coffees respond strongly to price changes. However, it could also be due to bargaining between roasters and retail chains. Reduction of shelf space is the main threat used by retail chains when roasters wish to increase wholesale prices. This threat is likely to be effective for coffees with small market shares, but not for the most popular ones. Moreover, when the cost of green coffee beans falls, retail chains might not lower retail prices fully for small coffees even if wholesale prices decline, or roasters might be unwilling to reduce wholesale prices for small coffees increase profits.

To conclude, the Swedish ground coffee market seems to be far from a typical monopolistic or oligopolistic market; pass-through rates are high, particularly for popular coffees. In fact, a large part of the market seems to be quite competitive, although there are deviations from perfect competition. Nevertheless, more research is needed to explain the systematic positive relationship between pass-through rates and market shares. 


\section{References}

Adachi, T., and Ebina, T. (2014a). Cost pass-through and inverse demand curvature in vertical relationships with upstream and downstream competition. Economics Letters, 124(3), 465-468.

Adachi, T., and Ebina, T. (2014b). Double marginalization and cost pass-through: Weyl-Fabinger and Cowan meet Spengler and Bresnahan-Reiss. Economics Letters, 122(2), 170-175.

Amiti, M., Itskhoki, O., \& Konings, J. (2014). Importers, exporters, and exchange rate disconnect. The American Economic Review, 104(7), 1942-1978.

Anderson, S. P., De Palma, A., and Kreider, B. (2001). Tax incidence in differentiated product oligopoly. Journal of Public Economics, 81(2), 173-192.

Aron, J., Macdonald, R., and Muellbauer, J. (2014). Exchange Rate Pass-Through in Developing and Emerging Markets: A Survey of Conceptual, Methodological and Policy Issues, and Selected Empirical Findings. Journal of Development Studies, 50(1), 101-143.

Atkeson, A. and Burstein, A. (2008). Pricing-to-Market, Trade Costs, and International Relative Prices. American Economic Review, 98(5), 1998-2031.

Auer, R. A., and Schoenle, R. S. (2016). Market structure and exchange rate pass-through. Journal of International Economics, 98, 60-77.

Besanko, D., J-P. Dubé and Gupta, S. (2005). Own-Brand and Cross-Brand Retail Pass-Through. Marketing Science, 24(1), pp. 123-137.

Bettendorf, L., and Verboven, F. (2000). Incomplete transmission of coffee bean prices: evidence from the Netherlands. European Review of Agricultural Economics 27(1), 1-16.

Bonnet, C., Dubois, P., Villas-Boas, S. B., and Klapper, D. (2013). Empirical evidence on the role of nonlinear wholesale pricing and vertical restraints on cost pass-through. Review of Economics and Statistics, 95(2), 500-515.

Bonnet, C., and Villas-Boas, S. B. (2016). An analysis of asymmetric consumer price responses and asymmetric cost pass-through in the French coffee market. European Review of Agricultural Economics 43 (5): 781-804.

Bulow, J. I., and Pfleiderer, P. (1983). A note on the effect of cost changes on prices. Journal of Political Economy, 91(1), 182-185.

Burstein, A., and Gopinath, G. (2014). International Prices and Exchange Rates. Handbook of International Economics, 4, 391-451, Amsterdam: Elsevier.

Consumers International (2005), From Bean to Cup: How Consumer Choice Impacts upon Coffee Producers and the Environment, Consumers International, London.

Daviron, B. and Ponte, S. (2005) The Coffee Paradox: Global Markets, Commodity Trade and the Elusive Promise of Development, ZED Books, London. 
Dicum, G. and Luttinger, N. (1999), The Coffee Book: Anatomy of an Industry From Crop to the Last Drop, New York: New Press.

Dornbusch, R. (1987). Real Exchange Rate and Prices. American Economic Review, 77(1), 93-106.

Durevall, D. (2003). Competition and Pricing: An Analysis of the Market for Roasted Coffee. Chap. 5 in High prices in Sweden - a result of poor competition?, Swedish Competition Authority Report

Durevall, D. (2007a). Demand for Coffee: The Role of Prices, Preferences and Market Power. Food Policy. Vol. 32, No. 5-6, pp. 566-584.

Durevall, D. (2007b).Competition in the Swedish Coffee Market 1978-2002. International Journal of Industrial Organization. Vol. 25, No. 4, pp. 721-739

Eichenbaum, M., N. Jaimovich, and Rebelo, S. (2011). Reference Prices, Costs, and Nominal Rigidities. American Economic Review, 101(1): 234-262.

Ericsson, N. R., and Mackinnon, J. G. (2002). Distributions of error correction tests for cointegration. The Econometrics Journal, 5(2), 285-318.

European Coffee Federation (2011). European Coffee Report 2010/2011, Rijswijk, The Netherlands.

Fairtrade International (2017). Driving Sales, Deepening Impact: Annual Report 2015 - 2016. Available at https://annualreport15-16.fairtrade.net/en/.

Fairtrade Foundation (2012). Fairtrade and Coffee, Commodity Briefing, London.

Feenstra, R.C., (2016). Advanced International Trade: Theory and Evidence. Princeton University Press.

Feuerstein, S. (2002), "Do Coffee Roasters Benefit from High Prices of Green Coffee?" International Journal of Industrial Organization, Vol. 20, pp. 89-118.

Fitter, R. and Kaplinsky, R. (2001). Who Gains from Product Rents as the Coffee Market Becomes More Differentiated? A Value Chain Analysis. IDS Bulletin Vol. 32 No. 3, pp. 69-82.

Gaudin, G. (2016). Pass-through, vertical contracts, and bargains. Economics Letters, 139, 1-4.

Gibbon, P. (2007). Africa, Tropical Commodity Policy and the WTO Doha Round. Development Policy Review, Vol. 25, No. 1, pp. 43-70.

Gilbert, C. (2007). Have we been Mugged? Market Power in the Coffee Industry. Working Paper, CIFERM and Department of Economics, Università degli studi di Trento.

Gilbert, C. (2008). Value chain analysis and market power in commodity processing with application to the cocoa and coffee sectors. Commodity Market Review 2007-08, pp. 5-38, FAO.

Gómez, M. I., Lee, J., \& Koerner, J. (2009). Do retail coffee prices raise faster than they fall? Asymmetric price transmission in France, Germany and the United States. Journal of International Agricultural Trade and Development, 1556, 175.

Green, D. (2005). Conspiracy of silence: old and new directions on commodities. Report, Oxfam, London. 
Hong, G. H., and Li, N. (2015). Market Structure and Cost Pass-Through in Retail. Forthcoming, Review of Economics and Statistics.

Hoover, K. D., Johansen, S., and Juselius, K. (2008). Allowing the data to speak freely: The macroeconometrics of the cointegrated vector autoregression. The American Economic Review, 98(2), 251-255.

International Trade Centre (2011). The Coffee Exporter's Guide, Geneva.

Johansen, S. (1991). Estimation and hypothesis testing of cointegration vectors in Gaussian vector autoregressive models. Econometrica: Journal of the Econometric Society, 1551-1580.

Juselius, K. (2001.) Unit roots and the demand for cigarettes in Turkey: Pitfalls and possibilities. Discussion Paper at the Economics Department, University of Copenhagen.

Juselius, K. (2006). The cointegrated VAR model: Econometric Methodology and Empirical Applications Oxford University Press. 457 pp.

Lee, J., and Gómez, M. I. (2013). Impacts of the End of the Coffee Export Quota System on International-to-Retail Price Transmission. Journal of Agricultural Economics, 64(2), 343-362.

Leibtag, E., Nakamura, A. Nakamura, E. and Zerom, D. (2007). Cost Pass-Through in the U.S. Coffee Industry. USDA Economic Research Report No. (ERR-38).

Levy, D. L. (2008). Political contestation in global production networks. Academy of Management Review, 33(4), 943-963.

Lloyd, T. A., McCorriston, S., Morgan, C. W., Poen, E., \& Zgovu, E. (2014). Retail price dynamics and retailer heterogeneity: UK evidence. Economics Letters, 124(3), 434-438.

McCorriston, S. (2013). Competition in the Food Chain. Working Paper (11), Transparency for Food Pricing (TRANSFOP).

McCorriston, S., Sexton, R.J. and Sheldon, I. M (2004). Vertical Market Structure, Commodity Exports and Trade Reform. Paper presented at $7^{\text {th }}$ Annual Conference on Global Economic Analysis, World Bank, June 2004, Washington, D.C., USA.

Moorthy, Sridhar, (2005). A general theory of pass-through in channels with category management and retail competition. Marketing Science 24(1), 110-122.

Morisset, J. (1998). Unfair Trade? The Increasing Gap between World and Domestic Prices in Commodity Markets during the Past 25 Years. World Bank Economic Review, 12 (3), 503-526.

Moore, M. (2003). A World without Walls: Freedom, Development, Free Trade and Global Governance. Cambridge University Press: Cambridge

Nakamura, E. and Zerom D. (2010). Accounting for Incomplete Pass-Through. Review of Economic Studies, 77(3), 1192-1230.

Oxfam (2002). Mugged: Poverty in Your Coffee Cup, Oxfam International and Make Fair Trade, London.

RBB Economics (2014). Cost pass-through: Theory, measurement, and potential policy implications. Report prepared for the Office of Fair Trading, London. 
Rohman, A. and Friberg, R. (2016). Price Rigidity in the Swedish Beer Market. Beiträge zur Jahrestagung des Vereins für Socialpolitik 2016: Demographischer Wandel - Session: Price-Setting Behavior of Firms, No. G11-V3.

Sexton, R. J. (2013). Market power, misconceptions, and modern agricultural markets. American Journal of Agricultural Economics, 95(2), 209-219.

Statistics Sweden (2007). Konsumentprisindex, Nettoprisindex, Harmoniserat index för konsumentpriser 2007, PR0101. Stockholm, Statistiska centralbyrån.

Statistics Sweden (2014). Konsumentprisindex (KPI) 2014 SCBDOK 3.2 PR0101. Stockholm, Statistiska centralbyrån.

Swedish Competition Authority (2011). Konkurrens och makt I den svenska livsmedelskedjan. Report prepared by Agrifood Economics Centre, Lund.

Sutton, J. (2007). Sunk Cost and Market Structure MIT Press, Cambridge, Massachusetts.

Talbot, J. M. 2004. Grounds for Agreement: The Political Economy of the Coffee Commodity Chain. Lanham: Rowman and Littlefield.

Talbot, J. M. (2011). The coffee commodity chain in the world-economy: Arrighi's systemic cycles and Braudel's layers of analysis. Journal of World-Systems Research, 17(1), 58-88.

Tyagi, R. K. (1999). A characterization of retailer response to manufacturer trade deals. Journal of Marketing Research, 36(4), 510-516.

World Vision (2014). Coffee's Hidden Kick: Labour Exploitation in the Global Coffee Industry. DTL Fact Sheet Coffee, World Vision Australia.

Weyl, E. G., and Fabinger, M. (2013). Pass-through as an economic tool: Principles of incidence under imperfect competition. Journal of Political Economy, 121(3), 528-583. 
Figure 1. Average price per kg of ground coffee and cost of imported green coffee beans in net of VAT 2010 SEK, 2009:3-2014:11

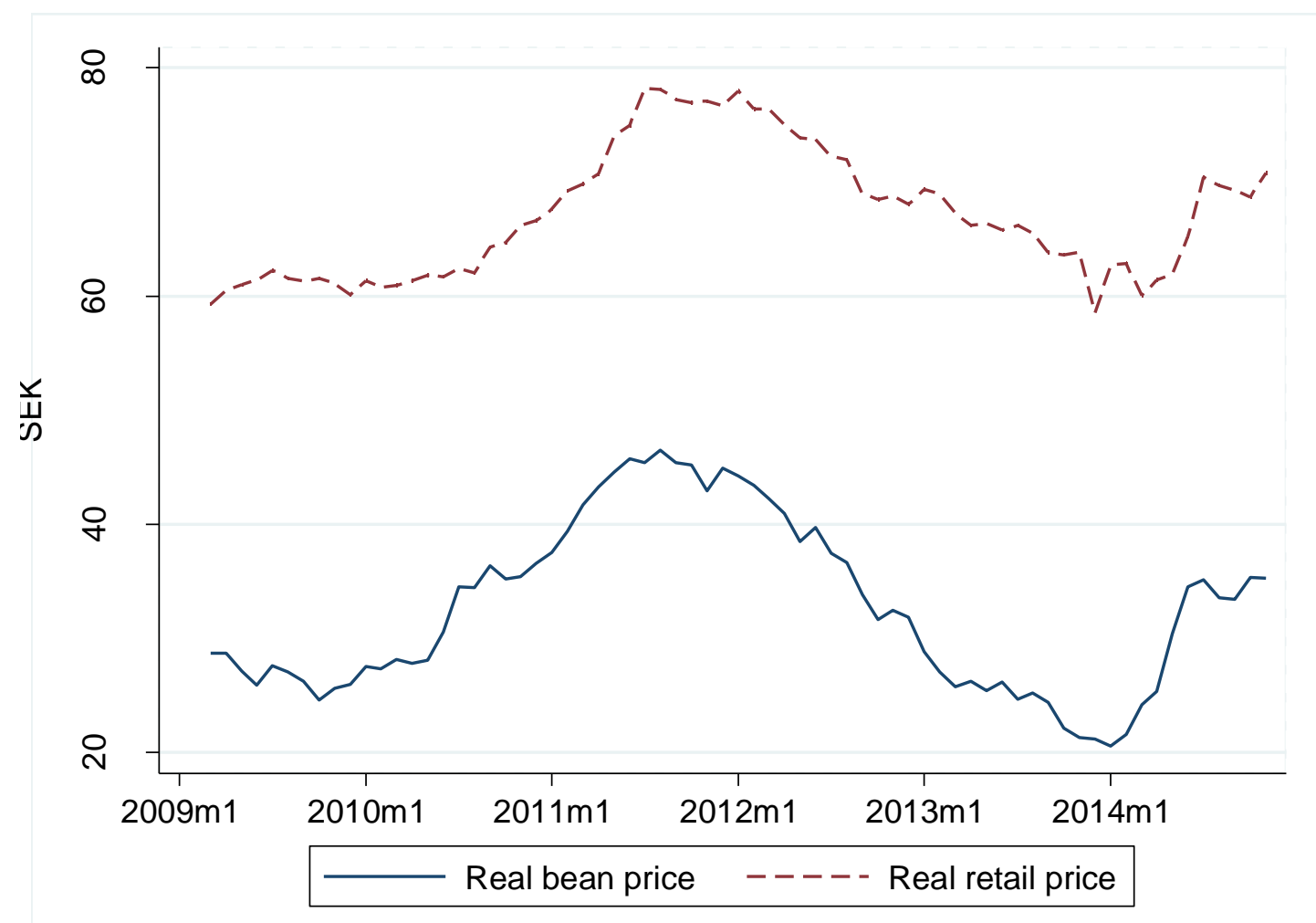

Figure 2. Estimates of pass-through rates for 378 products

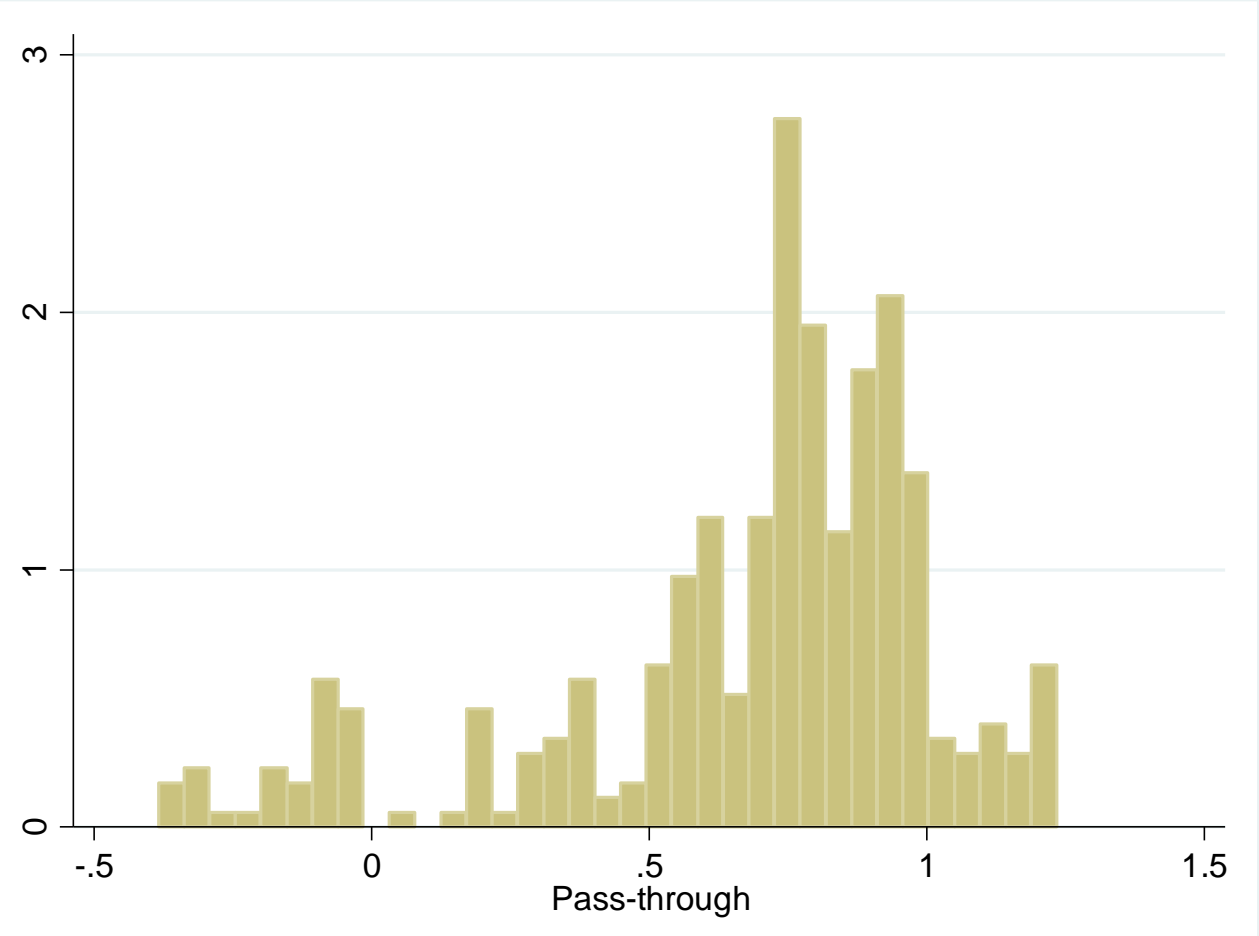

Notes: Estimates are based on unrestricted error correction models with one lag. One observation with a pass-through of 2.1 has been dropped. 
Figure 3. Pass-through rates for products and log of coffee market shares

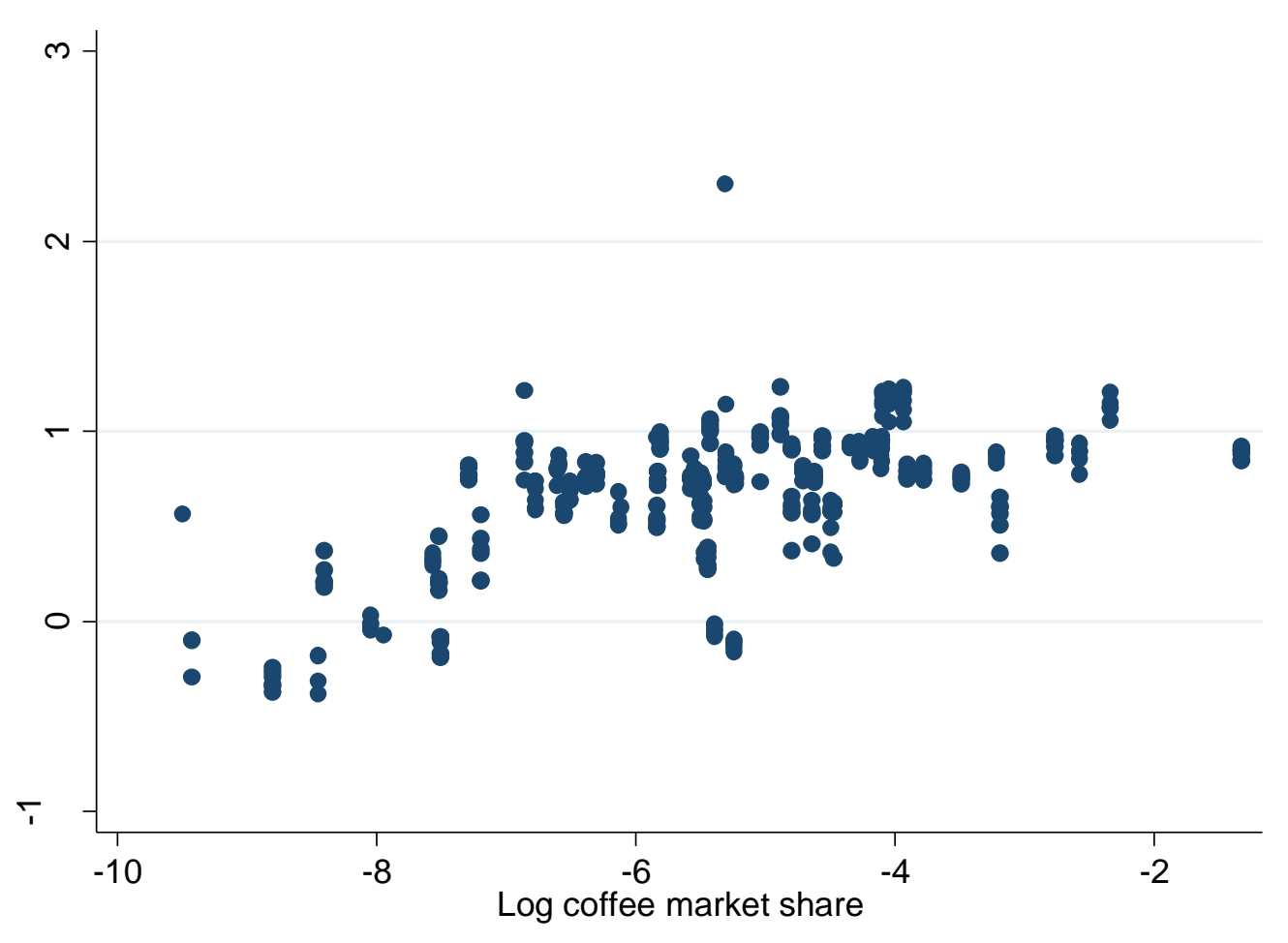

Figure 4: Pass-through rates for products and brand market shares

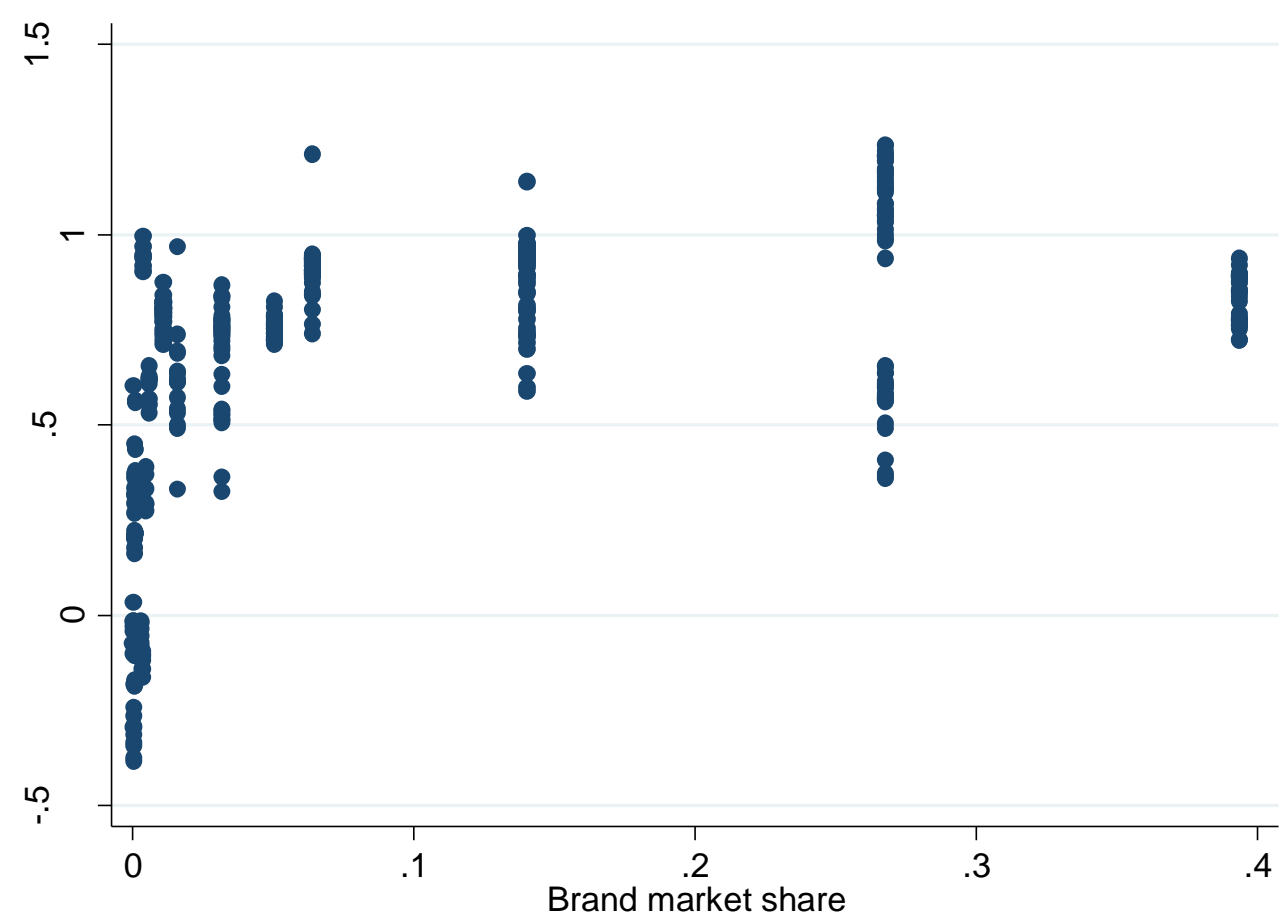

Note: Estimates are based on unrestricted error correction models with one lag. One observation with a pass-through of 2.1 has been dropped. 
Figure 5. Real prices of Gevalia Mellanrost Brygg, Gevalia Mellanrost E-brygg and the cost of beans

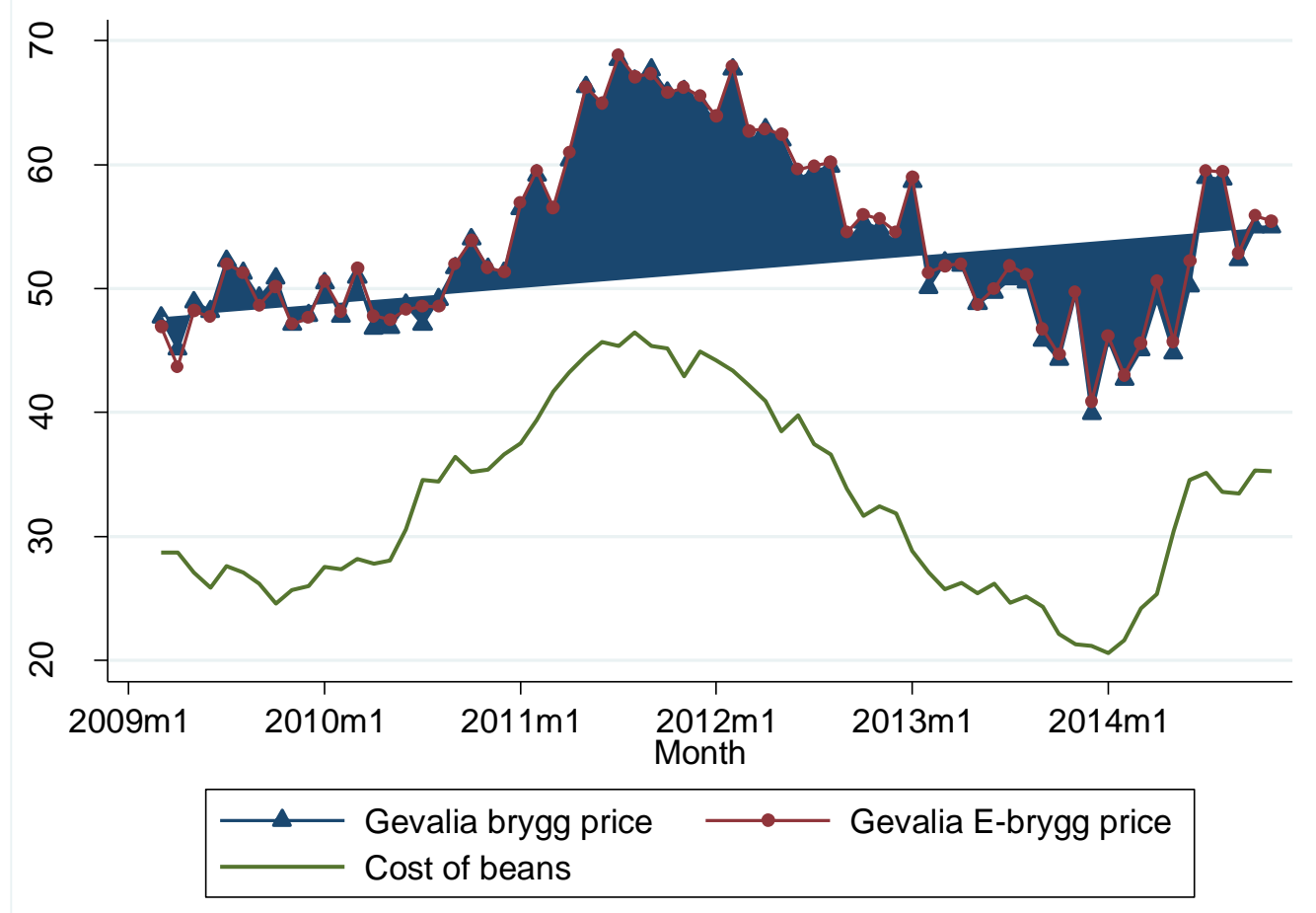

Figure 6. Real prices of Classic Mellan Brygg and Zoegas Skånerost and the cost of beans

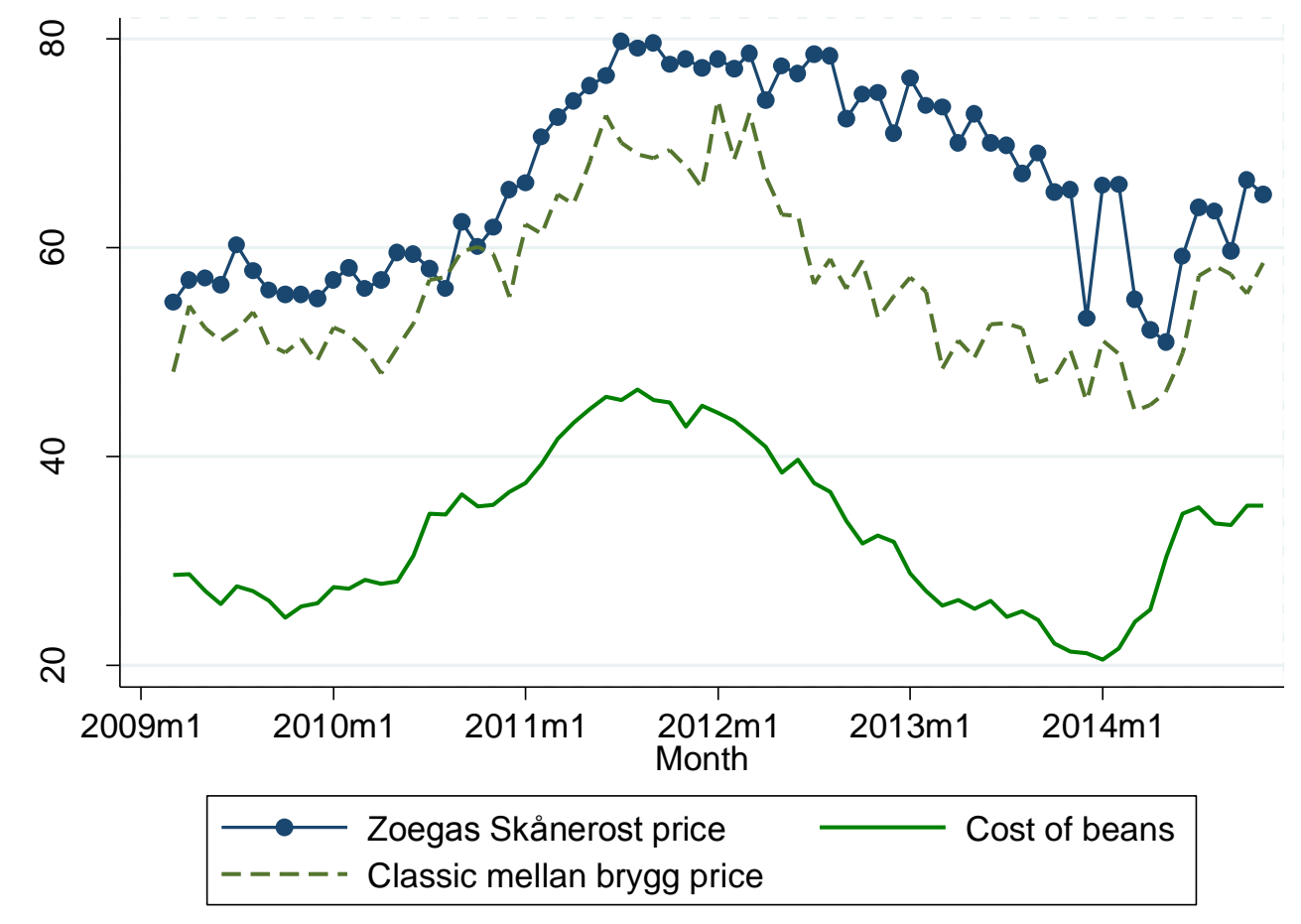


Table 1: Brands, coffees, products, market shares and average prices.

\begin{tabular}{|c|c|c|c|c|}
\hline Brand & Coffees & Products & Market share & Mean real price \\
\hline Gevalia & 5 & 30 & $39.37 \%$ & 59.04 \\
\hline Zoega & 10 & 60 & $26.80 \%$ & 70.63 \\
\hline Classic & 9 & 54 & $14.02 \%$ & 65.63 \\
\hline Löfbergs Lila & 7 & 38 & $6.41 \%$ & 57.67 \\
\hline ICA & 6 & 36 & $5.05 \%$ & 48.43 \\
\hline Blå Mocca & 3 & 18 & $3.18 \%$ & 61.75 \\
\hline Coop & 6 & 36 & $1.61 \%$ & 49.19 \\
\hline Änglamark & 1 & 6 & $1.10 \%$ & 62.74 \\
\hline Maxwell House & 1 & 6 & $0.59 \%$ & 68.56 \\
\hline Coop X-tra & 1 & 6 & $0.48 \%$ & 36.44 \\
\hline ICA I Love Eco & 2 & 12 & $0.36 \%$ & 59.72 \\
\hline Lindvall & 4 & 23 & $0.34 \%$ & 49.72 \\
\hline Euroshopper & 1 & 6 & $0.28 \%$ & 33.91 \\
\hline Sackeus & 2 & 7 & $0.11 \%$ & 79.74 \\
\hline Ideekaffe & 1 & 6 & $0.09 \%$ & 85.13 \\
\hline Folke Bergman & 1 & 1 & $0.08 \%$ & 47.52 \\
\hline Servtrade & 3 & 16 & $0.05 \%$ & 39.22 \\
\hline Najjar & 2 & 9 & $0.04 \%$ & 109.40 \\
\hline Other Brands & 2 & 7 & $0.03 \%$ & 66.60 \\
\hline Lyxkaffe & 1 & 1 & $0.00 \%$ & 38.68 \\
\hline Sum & 68 & 378 & $100 \%$ & \\
\hline
\end{tabular}


Table 2: Pass-through and market shares, ground coffee

\begin{tabular}{|c|c|c|c|c|c|c|}
\hline & (1) & (2) & (3) & (4) & (5) & (6) \\
\hline Product share & $\begin{array}{l}1.039 \\
(0.333)^{* *}\end{array}$ & $\begin{array}{r}3.268 \\
(1.171)^{* *}\end{array}$ & & & & \\
\hline Product share sq & & $\begin{array}{r}-5.761 \\
(2.255)^{*}\end{array}$ & & & & \\
\hline Coffee share & & & $\begin{array}{c}1.728 \\
(0.943)\end{array}$ & $\begin{array}{c}7.596 \\
(2.095)^{* *}\end{array}$ & & \\
\hline Coffee share sq & & & & $\begin{array}{c}-24.372 \\
(7.336)^{* *}\end{array}$ & & \\
\hline Brand share & & & & & $\begin{array}{c}0.468 \\
(0.245)\end{array}$ & $\begin{array}{c}2.253 \\
(1.260)\end{array}$ \\
\hline Brand share sq & & & & & & $\begin{array}{l}-3.641 \\
(2.241)\end{array}$ \\
\hline Najjar/Bosnia & $\begin{array}{l}-0.911 \\
(0.083)^{* *}\end{array}$ & $\begin{array}{r}-0.889 \\
(0.085)^{* *}\end{array}$ & $\begin{array}{c}-0.900 \\
(0.084)^{* *}\end{array}$ & $\begin{array}{c}-0.844 \\
(0.087)^{* *}\end{array}$ & $\begin{array}{c}-0.876 \\
(0.110)^{* *}\end{array}$ & $\begin{array}{c}-0.791 \\
(0.116)^{* *}\end{array}$ \\
\hline Constant & $\begin{array}{l}0.711 \\
(0.039)^{* *}\end{array}$ & $\begin{array}{r}0.689 \\
(0.042)^{* *}\end{array}$ & $\begin{array}{c}0.700 \\
(0.041)^{* *}\end{array}$ & $\begin{array}{c}0.642 \\
(0.046)^{* *}\end{array}$ & $\begin{array}{c}0.674 \\
(0.074)^{* *}\end{array}$ & $\begin{array}{c}0.579 \\
(0.093)^{* *}\end{array}$ \\
\hline$R^{2}$ & 0.30 & 0.32 & 0.31 & 0.37 & 0.31 & 0.35 \\
\hline$N$ & 378 & 378 & 378 & 378 & 378 & 378 \\
\hline
\end{tabular}

Notes: Najjar/Bosnia is a dummy for Najjar and Bosnia (Zlatna Dzezva) products, out of which all but one have negative pass-through rates. Standard errors are clustered at the product level except when brand shares are included; in which case clustering is at the brand level. ${ }^{*} \mathrm{p}<0.05 ; * * \mathrm{p}<0.01$. 
Table 3: Pass-through, private labels and large brands, ground coffee

\begin{tabular}{|c|c|c|c|c|c|c|}
\hline & (1) & (2) & (3) & (4) & (5) & (6) \\
\hline & Private label & $\begin{array}{c}\text { Brand } \\
\text { dummies }\end{array}$ & $\begin{array}{c}\text { Brand } \\
\text { dummies }\end{array}$ & $\begin{array}{l}4 \text { large } \\
\text { brands }\end{array}$ & Gevalia & Classic \\
\hline Coffee share & $\begin{array}{l}7.147 \\
(2.128)^{* *}\end{array}$ & & & $\begin{array}{c}1.631 \\
(1.834)\end{array}$ & $\begin{array}{c}2.369 \\
(0.442)^{* *}\end{array}$ & $\begin{array}{l}19.069 \\
(5.393)^{* *}\end{array}$ \\
\hline Coffee share sq & $\begin{array}{l}-23.840 \\
(7.480)^{* *}\end{array}$ & & & $\begin{array}{l}-5.789 \\
(6.548)\end{array}$ & $\begin{array}{c}-7.085 \\
(1.605)^{* *}\end{array}$ & $\begin{array}{l}-252.179 \\
(72.375)^{* *}\end{array}$ \\
\hline Classic & & $\begin{array}{c}0.354 \\
(0.086)^{* *}\end{array}$ & $\begin{array}{c}0.320 \\
(0.061)^{* *}\end{array}$ & & & \\
\hline Löfbergs lila & & $\begin{array}{l}0.413 \\
(0.087)^{* *}\end{array}$ & $\begin{array}{c}0.378 \\
(0.063)^{* *}\end{array}$ & & & \\
\hline Gevalia & & $\begin{array}{c}0.311 \\
(0.086)^{* *}\end{array}$ & $\begin{array}{l}0.267 \\
(0.057)^{* *}\end{array}$ & & & \\
\hline Zoega & & $\begin{array}{l}0.334 \\
(0.122)^{* *}\end{array}$ & $\begin{array}{c}0.325 \\
(0.104)^{* *}\end{array}$ & & & \\
\hline Private Disc & $\begin{array}{l}-0.752 \\
(0.071)^{* *}\end{array}$ & $\begin{array}{l}-0.602 \\
(0.091)^{* *}\end{array}$ & & & & \\
\hline Private Prem & $\begin{array}{l}-0.283 \\
(0.097)^{* *}\end{array}$ & $\begin{array}{l}-0.013 \\
(0.111)\end{array}$ & & & & \\
\hline Private Stand & $\begin{array}{c}0.003 \\
(0.058)\end{array}$ & $\begin{array}{c}0.191 \\
(0.085)^{*}\end{array}$ & & & & \\
\hline Dark roast & $\begin{array}{c}0.093 \\
(0.060)\end{array}$ & $\begin{array}{c}0.053 \\
(0.054)\end{array}$ & & & & \\
\hline Unknown roast & $\begin{array}{c}0.253 \\
(0.105)^{*}\end{array}$ & $\begin{array}{c}0.248 \\
(0.081)^{* *}\end{array}$ & & & & \\
\hline Organic & $\begin{array}{c}0.102 \\
(0.081)\end{array}$ & $\begin{array}{l}-0.016 \\
(0.054)\end{array}$ & & & & \\
\hline Odd size & $\begin{array}{l}-0.996 \\
(0.066)^{* *}\end{array}$ & $\begin{array}{l}-0.855 \\
(0.078)^{* *}\end{array}$ & $\begin{array}{l}-0.765 \\
(0.090)^{* *}\end{array}$ & & & \\
\hline Constant & $\begin{array}{c}0.632 \\
(0.072)^{* *}\end{array}$ & $\begin{array}{c}0.517 \\
(0.087)^{* *}\end{array}$ & $\begin{array}{c}0.565 \\
(0.052)^{* *}\end{array}$ & $\begin{array}{c}0.863 \\
(0.045)^{* *}\end{array}$ & $\begin{array}{c}0.750 \\
(0.012)^{* *}\end{array}$ & $\begin{array}{c}0.731 \\
(0.057)^{* *}\end{array}$ \\
\hline R2 & 0.57 & 0.65 & 0.49 & 0.01 & 0.64 & 0.49 \\
\hline $\mathrm{N}$ & 378 & 378 & 378 & 182 & 30 & 54 \\
\hline
\end{tabular}

Notes: Najjar/Bosnia is a dummy for Najjar and Bosnia (Zlatna Dzezva) products, out of which all but one have negative pass-through rates. Standard errors are clustered at the product level except when brand shares are included; in which case clustering is at the brand level. ${ }^{*} p<0.05 ; * * p<0.01$. 
Table 5: The error correction model

$$
\left(\begin{array}{l}
\Delta p_{\text {Gev }} \\
\Delta p_{\text {Zoe }} \\
\Delta p_{\text {cla }}
\end{array}\right)_{t}=\left(\begin{array}{ccc}
-0.58 & 0 & 0 \\
0 & -0.26 & 0 \\
0 & 0 & -0.60
\end{array}\right)\left(\begin{array}{l}
p_{\text {Gev }}-c_{\text {bea }} \\
p_{\text {Zoe }}-c_{\text {bea }} \\
p_{\text {cla }}-c_{\text {bea }}
\end{array}\right)_{t-2}+\left(\begin{array}{cccc}
-0.76 & 0 & 0 & 0.50 \\
0 & -0.5 & 0 & 0 \\
0.26 & 0 & -0.73 & 0.60
\end{array}\right)\left(\begin{array}{l}
\Delta p_{G e v} \\
\Delta p_{\text {Zoe }} \\
\Delta p_{\text {Cla }} \\
\Delta c_{\text {Bea }}
\end{array}\right)_{t-1}+D
$$

Note: All coefficients are significant at the $5 \%$ level, at least. See Tables A1 and A2 in the appendix for the general and parsimonious models. 


\section{Appendix: Additional figures and tables}

Figure A1. Long-run pass-through rates estimated with static models and unrestricted error correction models

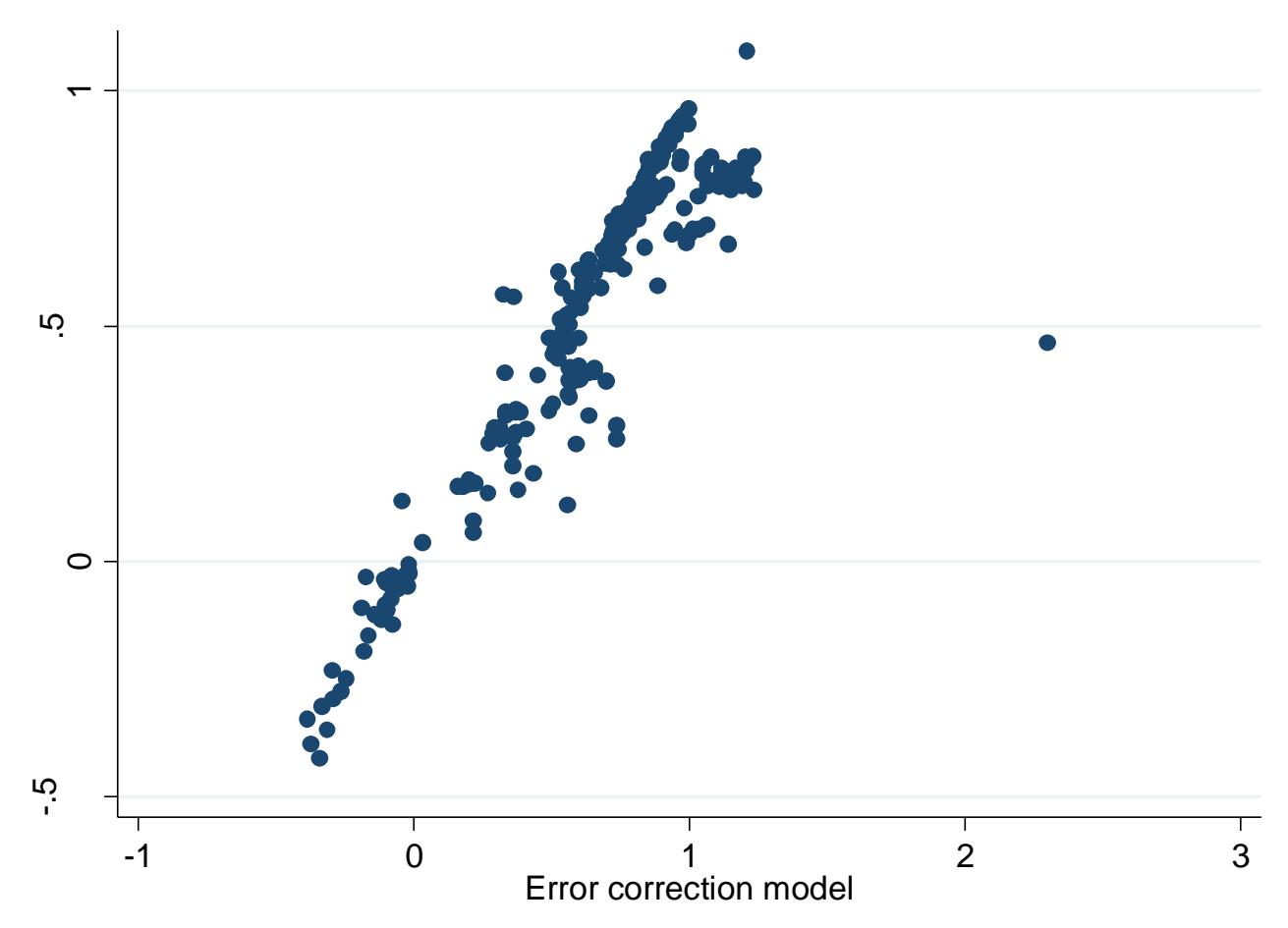

Figure A2. Long-run pass-through rates estimated with unrestricted error correction models and distributed lags model in log first differences, 24 lags.

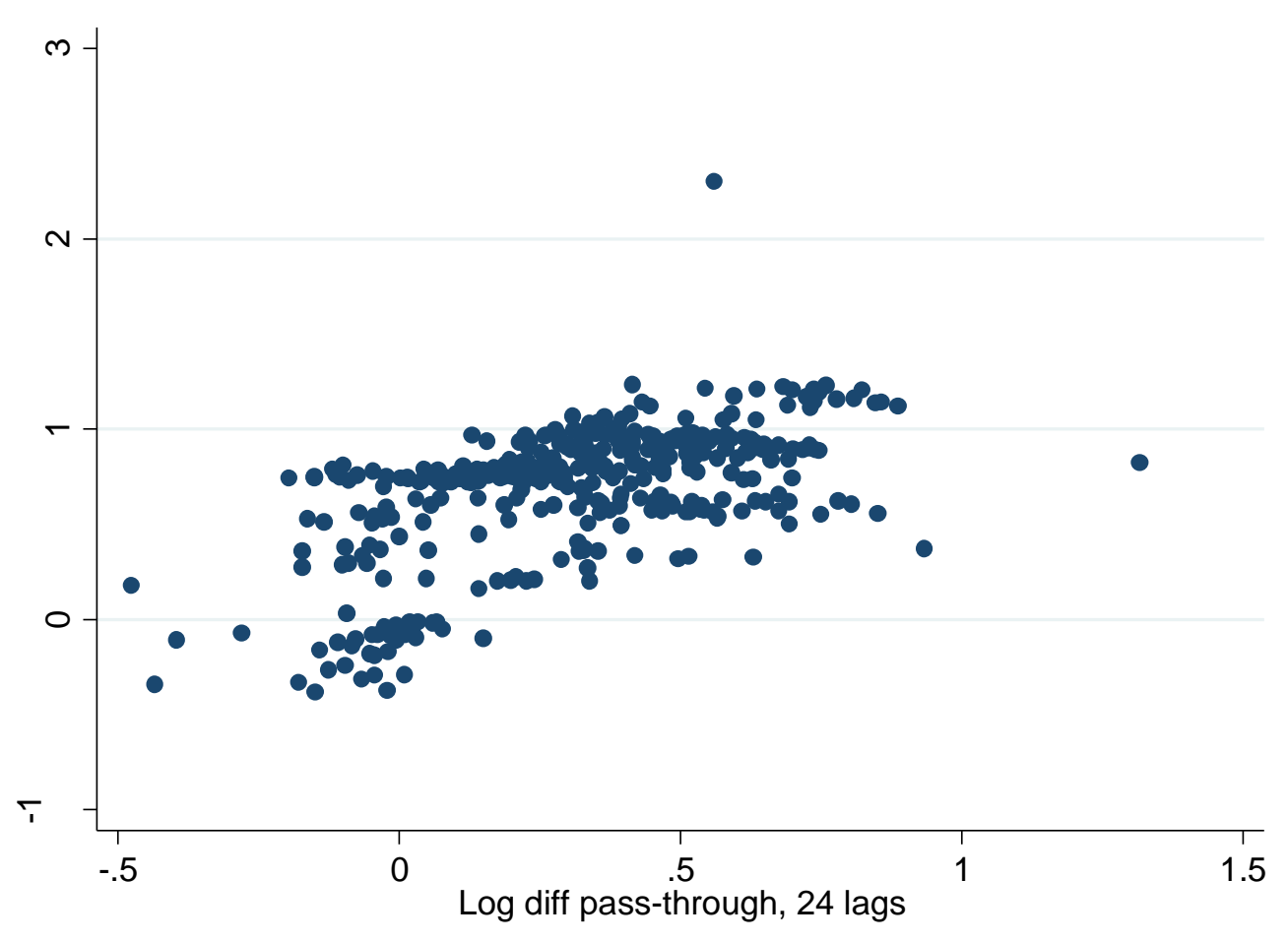




\section{Error correction models for eastern Sweden}

All prices are in 2010 constant prices and net of VAT. The variables are defined as:

Price of Gevalia Mellanrost Brygg $=$ PGev

Price of Zoegas Skånerost $=$ PZoe

Price of Classic Mellan Brygg = PCla

Coffee bean cost $=$ Cbea

$\Delta$ stands for first difference and_ $t$ for the lag of $t$ months.

The error correction terms, $\beta_{i}^{\prime} x_{t}$ are $\mathrm{Cia}, \mathrm{Clb}$ and Cic. They are specified as $\left(p-c_{\mathrm{Bea}}\right)_{t-2}$ where $p$ is the price of $P G e v, P Z o e$ and $P C l a$, respectively.

\section{Table A1: General error correction model}

Estimating the model by FIML. The estimation sample is: 2009(6) $2014(11)$

Equation for: $\triangle \mathrm{PGev}$

\begin{tabular}{llll} 
& Coefficient & Std.Error & t-value \\
\hline$\Delta$ PGev_1 & -0.780015 & 0.1393 & -5.6 \\
$\Delta$ PZoe_1 & -0.0763836 & 0.1101 & -0.694 \\
$\Delta$ PCla_1 & 0.0326761 & 0.124 & 0.263 \\
Cbea & 0.068252 & 0.2288 & 0.298 \\
Cbea_1 & 0.475726 & 0.2368 & 2.01 \\
Cla_2 & -0.591865 & 0.1344 & -4.4 \\
Constant & 12.7189 & 2.895 & 4.39 \\
CSeasonal & 3.59662 & 1.758 & 2.05 \\
CSeasonal_1 & 2.1718 & 1.872 & 1.16 \\
CSeasonal_2 & 1.52148 & 1.68 & 0.905 \\
CSeasonal_3 & 2.36421 & 1.708 & 1.38 \\
CSeasonal_4 & 1.48746 & 1.705 & 0.873 \\
CSeasonal_5 & 1.86577 & 1.612 & 1.16 \\
CSeasonal_6 & 3.76095 & 1.659 & 2.27 \\
CSeasonal_7 & 2.80972 & 1.651 & 1.7 \\
CSeasonal_8 & -0.504009 & 1.643 & -0.307 \\
CSeasonal_9 & 1.37346 & 1.668 & 0.823 \\
CSeasonal_10 & 1.93558 & 1.643 & 1.18 \\
\hline
\end{tabular}


Equation for: $\triangle \mathrm{PZOe}$

\begin{tabular}{llll} 
& Coefficient & Std.Error & t-value \\
\hline$\triangle \mathrm{PGev} 1$ & -0.268127 & 0.1345 & -1.99 \\
$\triangle \mathrm{PZoe} 1$ & -0.424526 & 0.1382 & -3.07 \\
$\triangle \mathrm{PCla} 1$ & -0.13828 & 0.1478 & -0.936 \\
Cbea & -0.05907 & 0.2809 & -0.21 \\
Cbea_1 & 0.0971268 & 0.2876 & 0.338 \\
CIb_2 & -0.291019 & 0.07039 & -4.13 \\
Constant & 10.1485 & 2.465 & 4.12 \\
CSeasonal & 4.93503 & 2.075 & 2.38 \\
CSeasonal_1 & 5.79483 & 2.225 & 2.6 \\
CSeasonal_2 & 0.819081 & 2 & 0.41 \\
CSeasonal_3 & 0.555308 & 2.026 & 0.274 \\
CSeasonal_4 & 3.79122 & 2.021 & 1.88 \\
CSeasonal_5 & 3.38289 & 1.911 & 1.77 \\
CSeasonal_6 & 4.77457 & 1.967 & 2.43 \\
CSeasonal_7 & 2.24246 & 1.959 & 1.14 \\
CSeasonal_8 & 1.41959 & 1.961 & 0.724 \\
CSeasonal_9 & 1.09329 & 1.985 & 0.551 \\
CSeasonal_10 & 2.75917 & 1.941 & 1.42 \\
\hline
\end{tabular}

Equation for:

\begin{tabular}{llll}
$\triangle \mathrm{PCla}$ & Coefficient & Std.Error & $\mathrm{t}$-value \\
\hline$\triangle \mathrm{PGeV} 1$ & 0.220499 & 0.0964 & 2.29 \\
$\triangle \mathrm{PZOe}$ 1 & 0.0223637 & 0.09295 & 0.241 \\
$\triangle \mathrm{PCla} 1$ & -0.720952 & 0.1349 & -5.35 \\
Cbea & 0.253723 & 0.1931 & 1.31 \\
Cbea_1 & 0.53041 & 0.1998 & 2.65 \\
CIC_2 & -0.577836 & 0.1461 & -3.96 \\
Constant & 13.8864 & 3.543 & 3.92 \\
CSeasonal & 6.42442 & 1.502 & 4.28 \\
CSeasonal_1 & 1.94576 & 1.591 & 1.22 \\
CSeasonal_2 & 1.52608 & 1.441 & 1.06 \\
CSeasonal_3 & 0.508001 & 1.446 & 0.351 \\
CSeasonal_4 & 0.963624 & 1.468 & 0.657 \\
CSeasonal_5 & 2.7636 & 1.388 & 1.99 \\
CSeasonal_6 & 2.25874 & 1.411 & 1.6 \\
CSeasonal_7 & 1.75087 & 1.407 & 1.24 \\
CSeasonal_8 & 0.764686 & 1.407 & 0.543 \\
CSeasonal_9 & 2.42558 & 1.427 & 1.7 \\
CSeasonal_10 & 1.98563 & 1.397 & 1.42 \\
\hline
\end{tabular}

log-likelihood -438.661847 , no.of observations 66 no. of parameters 54 
Table A1: Parsimonious error correction model

Estimating the model by FIML. The estimation sample is: 2009(6) $2014(11)$

Equation for: $\triangle \mathrm{PGev}$

\begin{tabular}{llll} 
& Coefficient & Std.Error & t-value \\
\hline$\triangle \mathrm{PGev} 1$ & -0.757095 & 0.1311 & -5.77 \\
Cbea_1 & 0.495362 & 0.206 & 2.4 \\
CIa_2 & -0.576713 & 0.128 & -4.51 \\
Constant & 12.3918 & 2.754 & 4.5 \\
CSeasonal & 3.7713 & 1.657 & 2.28 \\
CSeasonal_1 & 2.01312 & 1.671 & 1.2 \\
CSeasonal_2 & 1.50704 & 1.634 & 0.922 \\
CSeasonal_3 & 2.51647 & 1.638 & 1.54 \\
CSeasonal_4 & 1.63704 & 1.636 & 1 \\
CSeasonal_5 & 1.88256 & 1.57 & 1.2 \\
CSeasonal_6 & 3.79726 & 1.596 & 2.38 \\
CSeasonal_7 & 2.65078 & 1.59 & 1.67 \\
CSeasonal_8 & -0.392097 & 1.559 & -0.251 \\
CSeasonal_9 & 1.38863 & 1.596 & 0.87 \\
CSeasonal_10 & 1.97797 & 1.586 & 1.25 \\
\hline
\end{tabular}

Equation for: $\triangle \mathrm{PZOe}$

\begin{tabular}{llll} 
& Coefficient & Std.Error & t-value \\
\hline$\triangle$ PZoe_1 & -0.495891 & 0.1288 & -3.85 \\
CIb_2 & -0.258223 & 0.0627 & -4.12 \\
Constant & 9.00174 & 2.187 & 4.12 \\
CSeasonal & 5.5488 & 2.048 & 2.71 \\
CSeasonal_1 & 4.34197 & 2.052 & 2.12 \\
CSeasonal_2 & 1.25783 & 2.011 & 0.626 \\
CSeasonal_3 & 0.459945 & 2.028 & 0.227 \\
CSeasonal_4 & 3.40101 & 2.028 & 1.68 \\
CSeasonal_5 & 3.29928 & 1.929 & 1.71 \\
CSeasonal_6 & 4.44637 & 1.924 & 2.31 \\
CSeasonal_7 & 1.51574 & 1.93 & 0.785 \\
CSeasonal_8 & 1.14078 & 1.94 & 0.588 \\
CSeasonal_9 & 1.88931 & 1.933 & 0.977 \\
CSeasonal_10 & 2.32432 & 1.927 & 1.21 \\
\hline
\end{tabular}

Equation for: $\triangle \mathrm{PCla}$ 


\begin{tabular}{llll} 
& Coefficient & Std.Error & t-value \\
\hline$\triangle \mathrm{PGev} 1$ & 0.261453 & 0.08787 & 2.98 \\
$\triangle \mathrm{PCl}$ __1 & -0.726347 & 0.1313 & -5.53 \\
Cbea_1 & 0.601184 & 0.1853 & 3.24 \\
CIC_2 & -0.602857 & 0.1422 & -4.24 \\
Constant & 14.515 & 3.447 & 4.21 \\
CSeasonal & 6.12517 & 1.445 & 4.24 \\
CSeasonal_1 & 1.7072 & 1.56 & 1.09 \\
CSeasonal_2 & 1.62813 & 1.422 & 1.15 \\
CSeasonal_3 & 0.333542 & 1.407 & 0.237 \\
CSeasonal_4 & 0.816219 & 1.423 & 0.574 \\
CSeasonal_5 & 2.89204 & 1.368 & 2.11 \\
CSeasonal_6 & 2.01561 & 1.383 & 1.46 \\
CSeasonal_7 & 1.3731 & 1.372 & 1 \\
CSeasonal_8 & 0.379015 & 1.353 & 0.28 \\
CSeasonal_9 & 2.12197 & 1.383 & 1.53 \\
CSeasonal_10 & 1.75287 & 1.37 & 1.28 \\
\hline
\end{tabular}

log-likelihood -443.664359

no. of observations 66 no. of parameters 45

Vector SEM-AR 1-5 test: $F(45,101)=1.7023[0.0144]$ *

Vector Normality test: Chi^2(6) $=3.6186$ [0.7281]

Vector Hetero test: $F(210,156)=1.0548 \quad[0.3638]$

Tests of model reduction: $\mathrm{Chi}^{\wedge} 2(9)=0.005$ [0.3501] 